\title{
Structure-Bioactivity Relationships of Methylxanthines: Trying to Make Sense of All the Promises and the Drawbacks
}

\author{
João P. Monteiro ${ }^{1}$, Marco G. Alves ${ }^{2}$, Pedro F. Oliveira ${ }^{1,3}$ and Branca M. Silva ${ }^{2, *}$ \\ 1 Laboratory of Cell Biology and Unit for Multidisciplinary Research in Biomedicine (UMIB), \\ Department of Microscopy, Institute of Biomedical Sciences Abel Salazar (ICBAS), University of Porto, \\ 4050-313 Porto, Portugal; jpspmonteiro@yahoo.com (J.P.M.); pfobox@gmail.com (P.F.O.) \\ 2 Health Sciences Research Centre (CICS-UBI), University of Beira Interior, 6201-506 Covilhã, Portugal; \\ alvesmarc@gmail.com \\ 3 Institute of Health Research an Innovation, University of Porto, 4200-135 Porto, Portugal \\ * Correspondence: bmcms@ubi.pt; Tel.: +351-27-532-9077; Fax: +351-27-532-9099
}

Academic Editors: Marcello Iriti and Derek J. McPhee

Received: 22 April 2016; Accepted: 19 July 2016; Published: 27 July 2016

\begin{abstract}
Methylxanthines are a group of phytochemicals derived from the purine base xanthine and obtained from plant secondary metabolism. They are unobtrusively included in daily diet in common products as coffee, tea, energetic drinks, or chocolate. Caffeine is by far the most studied methylxanthine either in animal or epidemiologic studies. Theophylline and theobromine are other relevant methylxanthines also commonly available in the aforementioned sources. There are many disseminated myths about methylxanthines but there is increased scientific knowledge to discuss all the controversy and promise shown by these intriguing phytochemicals. In fact, many beneficial physiologic outcomes have been suggested for methylxanthines in areas as important and diverse as neurodegenerative and respiratory diseases, diabetes or cancer. However, there have always been toxicity concerns with methylxanthine (over)consumption and pharmacologic applications. Herein, we explore the structure-bioactivity relationships to bring light those enumerated effects. The potential shown by methylxanthines in such a wide range of conditions should substantiate many other scientific endeavors that may highlight their adequacy as adjuvant therapy agents and may contribute to the advent of functional foods. Newly designed targeted molecules based on methylxanthine structure may originate more specific and effective outcomes.
\end{abstract}

Keywords: caffeine; cancer; diabetes; methylxanthine; neurodegenerative diseases; structure-activity relationship; theobromine; theophylline

\section{Introduction}

Xanthines are compounds that are produced by both plants and animals. They have not yet been studied as thoroughly as other substances involved in metabolism, despite belonging to the purines family. Xanthine is in fact commonly considered the point of convergence for the purine base metabolism since both adenine and guanine nucleotides converge at this common intermediate [1,2]. Xanthine is involved in the catabolism of nucleotides and nucleic acids, since it is the precursor of uric acid, the final product of the catabolism of the purines [3].

Methylated xanthines (or methylxanthines) are produced in considerable amounts in a limited number of botanical species, including tea (Camellia sinensis L.), coffee (Coffea sp.) and cacao (Theobroma cacao L.), as we will further develop in Section 3 of this review. The most relevant methylxanthines are caffeine, theobromine and theophylline. It has been proposed that plants started biosynthesizing methylxanthines as protection against pathogens and predators, namely insects $[4,5]$. 
Methylxanthine consumption is generalized nowadays and started a long time ago. Historical and anthropological data suggest that it may be the result of a human quest for foods/beverages that contained nutrients and/or substances with added value in terms of well-being, other than just calorically [6]. In fact, other than the more common coffee, tea or cacao, other methylxanthine-containing beverages have been used in different cultures, like tejate, which has been used ceremonially in Mexico since pre-Hispanic times [7]. Caffeine and theophylline (this one typically at lower quantities) are present in coffee, tea, cola beverages and chocolate. Theobromine is also present in chocolate products and tea, and is also a caffeine metabolite in humans and other animal species. Paraxanthine, another important caffeine metabolite, is not found naturally in foods [8]. Other than the historically common methylxanthine sources, there are other products that are quickly growing in public preference that deserve careful attention. That is the case of energetic drinks and many food supplements formulated with these ingredients, which are thriving in Western societies right now.

There are a number of widespread myths about methylxanthines. Accepting the stipulation that moderate coffee consumption ranges from 1-3 cups per day (representing roughly $300 \mathrm{mg}$, if considering instant coffee) and high consumption from 3-6 cups (up to $600 \mathrm{mg} /$ day), one first rather disseminated myth prompts moderate caffeine consumption to be perceived by some to be bordering on dangerous. Therefore, there are those abstaining from drinking coffee and other caffeine-containing drinks based on the assumption that caffeine is (only) bad for you, and that caffeine has no positive effects. This myth will be debunked later in this review. Another common myth would be that decaffeinated coffee does not contain caffeine at all, while in fact it still contains it, although in considerably smaller amounts (normally $<5 \%$ of the amount found in caffeinated coffee). Another usual misconception would be the public perception of caffeine content in tea, which is normally considered to be high in black tea, lower in green, and next to nothing in white tea, while in fact, caffeine levels may overlap between tea types.

Caffeine is the more thoroughly studied methylxanthine to date, what reflects the prevalence of its consumption in today's society. Caffeine was first isolated from tea and coffee in the early 1820s [9], and it is probably one of the earliest known examples of functional ingredients sought after by consumers. Caffeine is widely perceived as a central nervous system (CNS) stimulant, and despite the many associated myths its use has been culturally accepted throughout the ages. It acts like a brain cortex stimulant, and is usually sought for by those looking for a general sense of mental energy, with increased awareness and wakefulness, improved clear thinking and attenuated fatigue [10,11]. Caffeine has received a lot of attention, even from sport regulatory institutions. It was reported as enhancing a wide range of exercise activities from those relying on explosive strength [12], to short-term, high-intensity exercise [13,14], to exercise that depends on aerobic activity and endurance [15-17], and its use was regulated by the International Olympic Committee (positive controls for more than $12 \mathrm{mg} / \mathrm{mL}$ of urine) [18].

As for theophylline, it showed promise as CNS stimulant, although it is mainly used in respiratory disease therapy (namely chronic obstructive pulmonary disease and asthma [19]). It has also been proposed as having applications as a diuretic [20]. Theobromine has showed significant less CNS activity than caffeine and theophylline, possibly because of physicochemical properties that hinder its distribution in the CNS [21].

Herein, we attempt to accomplish a comprehensive compilation of the reported data available regarding the physiological effects of methylxanthines, with special emphasis on caffeine, theophylline and theobromine. We will review the available literature, focusing on the structure-activity relationships that substantiate both beneficial and toxic effects, contextualize where methylxanthine pharmacologic use stands right now, and envision future developments and applications. 


\section{Definition and Chemical Structures}

Xanthine is a purine base found in most human tissues and fluids, as well as in other organisms. Methylxanthines are methylated derivatives of xanthine. They are heterocyclic organic compounds built from coupled pyrimidinedione and imidazole rings [22]. The most relevant naturally occurring methylxanthines (Figure 1) are caffeine (1,3,7-trimethylxanthine), theophylline (1,3-dimethylxanthine) and theobromine (3,7-dimethylxanthine). Paraxanthine (1,7-dimethylxanthine), an isomer of theobromine and theophylline, is not produced by plants but is the major dimethylated byproduct of caffeine. Aminophylline (1,3-dimethyl-7H-purine-2,6-dione), pentoxifylline (1-(5-oxohexyl)-3,7-dimethylxanthine), and IBMX (3-isobutyl-1-methylxanthine) are examples of more complexly substituted methylxanthines.<smiles>Cn1c(=O)c2c(ncn2C)n(C)c1=O</smiles><smiles>Cn1cnc2c1c(=O)[nH]c(=O)n2C</smiles><smiles>Cn1c(=O)c2[nH]cnc2n(C)c1=O</smiles><smiles>Cn1c(=O)[nH]c2ncn(C)c2c1=O</smiles>

Figure 1. Chemical structures of the three major natural methylxanthines (caffeine, theophylline and theobromine) and paraxanthine.

Unlike the others, caffeine was proposed to hold more lipophilic characteristics [21], what should substantiate its ability to easily diffuse through cell membranes and cross the blood-brain barrier [23]. Methylxanthines are weak Brønsted bases and this property should be related with the imino nitrogen at position 9. Theophylline lacks a methyl group at position 7 with regard to the other more relevant methylxanthines, containing instead at that position a proton which can be donated. While caffeine possesses electrophilic sites at positions 1,3 and 7 , theophylline has the same electrophilic predisposition at 1 and 3, in addition to its Brønsted acid site at position 7. The implications of this difference are that, even if both compounds are electron-pair donors, only theophylline is a proton donor in most pharmaceutical systems [24]. Theobromine differs from caffeine by lacking the methyl group at position 1 . That single methyl group is enough to confer caffeine different physicochemical properties that were reported to result in substantial increased physiological effects in some contexts [25]. Several synthetic modifications of naturally occurring methylxanthines have been designed with pharmacological intentions, including dyphylline (7-(2,3-dihydroxypropyl)-1,3-dimethyl-3,7-dihydro-1H-purine-2,6-dione), proxyphylline (7-(2-hydroxypropyl)-1,3-dimethylpurine-2,6-dione) and enprofylline (3-propyl-7H-purine-2,6dione) [26].

\section{Natural Sources of Methylxanthines and Biosynthesis}

Methylxanthines have been detected in nearly 100 species of 13 orders of the plant kingdom [27,28]. Coffea species' content in caffeine is estimated to be 0.4 to $2.4 \%$ dry weight [29]. Caffeine content is $2 \%-3 \%$ dry weight in young leaves of first flush shoots of Camellia sinensis, Camellia assamica and Camellia taliensis, but it represents less than $0.02 \%$ in Camellia kissi [9]. While in tea (infusion), caffeine may reach between $1.0 \%$ and $3.5 \%$ of the composition [30,31]. Despite caffeine being generally the major 
purine present in tea, some Camellia species accumulate theobromine instead of caffeine, although cacao (Theobroma cacao) is the major natural source of this methylxanthine. Theobromine is, in fact, the predominant one in the seeds of cacao, representing 1.9\% [9]. Although considerable amounts of caffeine and theobromine may be consumed from dietary sources (coffee, tea, cola beverages and chocolate) only relatively small amounts of theophylline are thought to be ingested from the same sources [8]. Theophylline occurs naturally in tea and in trace amounts in cocoa and coffee beans [19]. Theobromine levels have been reported to represent only $0.15 \%-0.46 \%$ in different types of chocolate [32]. Young maté (Ilex paraguariensis A. St.-Hil.) leaves were reported to contain $0.8 \%$ to $0.9 \%$ caffeine, $0.08 \%$ to $0.16 \%$ theobromine and less than $0.02 \%$ theophylline. Other plants reported as producing methylxanthines include Paullinia sp. (like guarana), Cola sp. and Citrus sp. [33-36]. No known plant or food contains paraxanthine [32]. In Table 1, the most common dietary sources and their content in methylxanthines are summarized. Many plants containing methylxanthines, such as coffee, tea, maté, kola nuts, and cocoa beans are commonly used in the production of beverages and foods ingested daily by many people. Tea and coffee are some of the most consumed beverages in the world, and two of the major sources of caffeine intake through diet [37]. Tea is expected to contain less caffeine with regard to coffee [38]. While coffee has been always mostly requested by those seeking a general sense of increased awareness and awakeness, therapeutic connotations have always been suggested for tea. Tea is a complex mixture of about 2000 chemical compounds which include proteins, polysaccharides, minerals and trace elements, organic acids, lignins, polyphenols, methylxanthines and amino acids $[39,40]$. Within this complex mixture, there are many bioactive compounds believed to promote health benefits [39,41-43]. Significant changes were thought to take place in tea composition depending on the type of tea in question and how it has been processed [44]. However, a very recent study by Boros and co-workers reported that caffeine content in commercial teas (white, green, oolong, black, and pu-erh) does not significantly differ according to the processing methods [45].

Table 1. Main sources of methylxanthines in diet.

\begin{tabular}{|c|c|c|c|c|}
\hline \multirow{2}{*}{\multicolumn{2}{|c|}{ Dietary Source }} & \multicolumn{3}{|c|}{ Medium Content (mg) } \\
\hline & & \multirow{3}{*}{$\begin{array}{c}\text { Caffeine } \\
140(51-532 \text { range) [46] } \\
3.0-15.8 \text { range [47] }\end{array}$} & \multirow{3}{*}{ 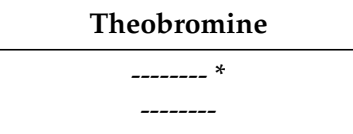 } & \multirow{3}{*}{$\begin{array}{c}\text { Theophylline } \\
------ \\
\text {----- }\end{array}$} \\
\hline & Expresso $(23-70 \mathrm{~mL})$ & & & \\
\hline Cotfee & Decaffeinated (30 mL) & & & \\
\hline \multirow{2}{*}{ Tea } & Black (200-235 mL) & 55.7 (41.6-71.2 range) [48] & $1.8-3.6[49]$ & $<1[50]$ \\
\hline & Green $(200-235 \mathrm{~mL})$ & 31.0 (20.2-42.8 range) [48] & $0.2-0.7[51]$ & --2. \\
\hline \multirow{2}{*}{ Chocolate } & Dark (100 g) & $0.22-0.31$ range [52] & $0.26(0.26-1.16$ range $)[53]$ & $0-9$ [54] \\
\hline & Milk (100 g) & $0.05-0.17$ range [52] & 0.17 (0.09-0.28 range) [53] & $5[54]$ \\
\hline \multirow{2}{*}{ Soft-Drink } & Cola $(330 \mathrm{~mL})$ & 32 & 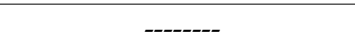 & 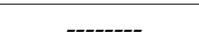 \\
\hline & Diet Cola (330 mL) & 42 & -------- & -------- \\
\hline Energy Drinks & Red Bull (250 mL) & 80 & ------- & |------ \\
\hline
\end{tabular}

In plants, methylxanthines are formed from purine nucleotides. Xanthosine, the initial substrate of methylxanthines biosynthesis, may be supplied by different pathways, which include de novo purine biosynthesis (de novo route), degradation of adenine nucleotides (AMP route), the S-adenosyl methionine cycle (SAM route) and guanine nucleotides (GMP route) [55]. Caffeine anabolism is based on steps identical or similar to the anabolism of other methylxanthines. The dominant pathway of caffeine production in higher plants is a xanthosine to 7-methylxanthosine, to 7-methylxanthine, to theobromine, to caffeine pathway $[55,56]$. This pathway involves consequent methylation of xanthosine, 7-methylxanthine and theobromine and hydrolysis of ribose from 7-methylxanthosine, each onto the next compound of the sequence [55,57]. The enzymes proposed as being involved in the consecutive reactions are 7-methylxanthosine synthase, $N$-methyl nucleosidase, theobromine synthase and caffeine synthase $[9,56]$. The rate of caffeine biosynthesis is primarily regulated by the induction 
or repression of $N$-methyltransferases, with special focus on 7-methylxanthosine synthase. Therefore, the rate-limiting step in the caffeine biosynthetic pathway is the initial conversion of xanthosine to 7-methylxanthosine, catalysed by 7-methylxanthosine synthase [55].

In contrast to theobromine, theophylline is more of a catabolite of caffeine than a precursor in plants. Caffeine is slowly degraded by consecutive removal of the three methyl groups, resulting in the formation of xanthine in almost all caffeine-forming plant species, with theophylline being a mid-product of the process [55]. Caffeine [58], theobromine [59] and theophylline [60] may also be obtained by chemical synthesis.

\section{Extraction, Identification and Quantification}

Many different technical approaches have been used to determine the methylxanthines profile of samples of many different types and sources. In fact, it is very easy to find many proposed protocols for the simultaneous determination of the main methylxanthines (caffeine, theobromine and theophylline) in food, beverages and even biological fluids.

Starting with sample preparation, several different pre-treatment protocols have been reported to eliminate unwanted matrix interferences in the determinations, including liquid-liquid extraction [61-66], solid-phase extraction [67-71] and even microwaves-assisted extraction [72]. After crude sample pre-treatment, methylxanthine extraction may be achieved by a process including sequential aqueous extraction of raw materials, followed by organic solvent extraction. Water was reported as being a good solvent for methylxanthines, although highly nonselective [73]. Liquid extraction using solvents such as methylene chloride, chloroform, methanol and $n$-hexane, has been used for methylxanthine extraction from natural plants [44,74-77]. However, most of the more recently pre-treatment methods proposed to be carried out before analytical procedures are rather simpler. In the case of liquid samples (like tea) direct sample application is sometimes an option [50,78,79]. In the case of solid samples (powders, chocolate, leaves), a small amount (in the gram range) is sometimes simply added and extracted in heated (sometimes boiling) stirred water, with posterior filtration $[50,71,79,80]$.

After the pre-treatment and extraction steps, a wide range of analytical techniques have been used for the analysis and quantification of the main methylxanthines including capillary gas chromatography (GC) [81], gas chromatography-mass spectrometry (GC-MS) [82,83], spectrophotometry [77,84-86], Fourier transform-Raman spectrometry [87], spectrofluorimetry [88,89], Fourier transform-infrared spectrophotometry [90], capillary electrophoresis (CE) [91-93] and micellar electrokinetic electrophoresis (MEKC) [94-96], voltammetry [97,98], radioimmunoassay (RIA) [99,100], thin-layer chromatography (TLC) $[68,101,102]$ ion-exchange chromatography [103] and even solid-phase ultraviolet sensing [104]. Supercritical fluid extraction, specifically using supercritical carbon dioxide and ethanol, has been proved to be an effective method for methylxanthine analysis from a number of different samples/sources (guaraná seeds, maté leaves, and cocoa beans) [73]. However, liquid chromatography (LC), more specifically reversed-phase high-performance liquid chromatography (RP-HPLC), has been the most common method of choice used for methylxanthine determination and quantitation. HPLC determination may rely on many different elution modes and mobile phases, as well as detectors. Spectrophotometric detection (DAD or UV, at or about $273 \mathrm{~nm}$, the wavelength normally used to detect xanthines $[40,105])$ is the most commonly used, but amperometric [106], and mass spectrometric detection [107-109] have also been employed. HPLC separation and quantification methods targeted at the simultaneous analysis of the main methylxanthines in samples rely on the use of C18 separation columns and mobile phases with various compositions, including different combinations of several solvents, with the most commonly used mixtures being water + methanol/ethanol + acetic acid [50,78,108] or water + acetonitrile $[44,71,109]$. Effective separation has been achieved either by isocratic $[50,71,78,79,108]$ or gradient $[40,44,109]$ elution profiles. 
More recent technical advances include the use of HPLC methods coupled to mass spectrometry detection. These approaches are very convenient, since they provide structural information and unequivocal identification of the compounds. These mass-spectrometric approaches use positive-mode electrospray ionization (ESI) and may rely on multiple reaction monitoring (MRM) for each of the target methylxanthine species for identification and quantification, monitoring two mass transitions (parent ion and product ion) for each analyte [109]. Several ions $[\mathrm{M}+\mathrm{H}]^{+}$have been proposed for identification and quantification purposes $[110,111]$ (Table 2).

Table 2. Mass spectrometric and MS/MS fragmentation patterns of caffeine, theophylline and theobromine [110].

\begin{tabular}{ccc}
\hline Methylxanthine & {$[\mathbf{M}+\mathbf{H}]^{+}$} & MS Data (MS/MS Fragmentation Pattern) \\
\hline Caffeine & 195.2 & $181.2,151.2,138.0$ \\
Theophylline & 181.2 & $167.2,153.2,123.5$ \\
Theobromine & 181.2 & $167.2,153.2,107.5$ \\
\hline
\end{tabular}

\section{Molecular Targets and Structure-Activity Relationships}

All of the naturally occurring methylxanthines have been reported to exert pharmacological effects, the potency of which may be determined by the compound structure itself, the species, the target organ and metabolizing enzyme system idiosyncrasies [32].

Several systematic effects have been described for the main methylxanthines in humans. Caffeine stimulates the CNS and respiratory system, while theophylline is less potent on these targets and theobromine is viewed as virtually inactive in this respect [112]. Theophylline is more effective than caffeine in cardiac stimulation, coronary dilatation and smooth muscle relaxation. As for theobromine, it is generally less active than caffeine or theophylline [112], although it has been reported to be a potent cardiac stimulant, being in fact previously used in humans as a dilator of coronary arteries (daily doses of 300-600 mg) [113]. The relative potencies of these methylxanthines with regard to the aforementioned pharmacological effects is summarized in Table 3. Regarding paraxanthine, its pharmacological effects and toxicological potency on these organ systems were suggested to be negligible [32].

Table 3. Relative pharmacological potencies of the naturally available methylxanthines ranging from more potent $(+++)$ to less potent $(+)$ (adapted from $[24,26,114]$ ).

\begin{tabular}{cccc}
\hline Systematic Effect & Caffeine & Theobromine & Theophylline \\
\hline CNS Stimulation & +++ & + & ++ \\
Respiratory Stimulation & +++ & + & ++ \\
Diuresis & ++ & + & +++ \\
Coronary Dilatation & + & ++ & +++ \\
Cardiac Stimulation & + & ++ & +++ \\
Skeletal Muscle Stimulation & +++ & + & ++ \\
Smooth Muscle Relaxation (Bronchodilation) & + & + & +++ \\
\hline
\end{tabular}

Available data helped build a relationship between the potency of each methylxanthine (as presented in Table 3) and the place where substitutions occur in the basic xanthine molecular structure [115] (Figure 2). These evidences imply that strict structure-activity relations modulate the discriminative stimuli elicited by methylxanthines on these specific physiologic effects. 


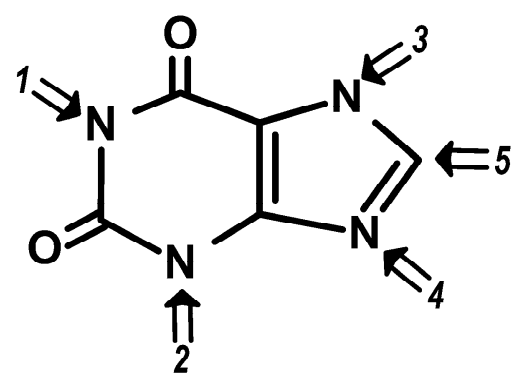

Figure 2. Effects of the structural substitutions of the xanthine molecule on adenosine antagonism and systematic effects: 1 . Substitution in position 1 is necessary for high affinity and selectivity towards adenosine receptor sites [116]. 2. Substitution in position 3 increases bronchodilator effect $[117,118]$. 3. Substitution in position 7 decreases both adenosine receptor antagonism and bronchodilator potency $[116,117,119]$. 4. Substitution in position 9 results in decreased adenosine receptor affinity $[119,120]$. 5 . Substitution in position 8 increases adenosine antagonism and selectivity towards $\mathrm{A}_{1}$ receptors [116,121,122].

Some of the beneficial effects reported for methylxanthines may be associated with the antioxidant properties ascribed to these compounds. Studies reveal that caffeine is an efficient scavenger of hydroxyl radicals and alkoxyl radicals [123] and this can support the antioxidant role proposed for this compound in protecting against cellular damage by decreasing lipid peroxidation [124,125]. Other than caffeine, theobromine (and xanthine) also exhibit antioxidant properties, and are able to bind and reduce $\mathrm{Cu}(\mathrm{II})$ to $\mathrm{Cu}(\mathrm{I})$. These properties of caffeine and its metabolites were suggested as contributing to the overall chemopreventive properties of caffeine-containing beverages, such as tea [126].

Despite the positive effects that the antioxidant properties of methylxanthines may originate, their pharmacological activities are normally related to other physiologic activities. Normally, four different mechanisms are proposed to mediate the pharmacological methylxanthine activity at the cellular level: antagonism of adenosine receptors, phosphodiesterase inhibition, modulation of GABA receptor action, and regulation of intracellular calcium levels [127-132] (Figure 3).

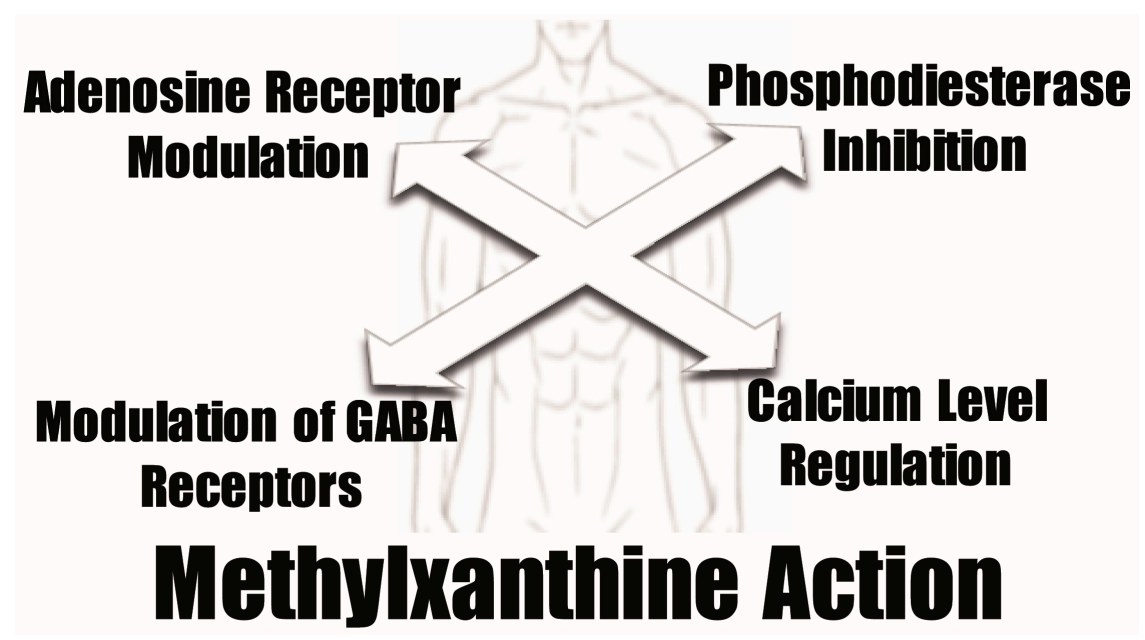

Figure 3. Main mechanisms proposed to mediate the pharmacological activity of methylxanthines at the cellular level.

The most important mechanism of action of methylxanthines involves blocking the adenosine receptors and competitively inhibiting the action of adenosine in the cells. This inhibition results in increased release of hormones, such as norepinephrine, dopamine and serotonin [133]. There are four different types of adenosine receptors and their widespread distribution, fits the proposal of the presence of adenosine in every cell although with differential cell/tissue expression. Adenosine may 
exert multiple actions in the central nervous, but also on the cardiovascular and even other systems, all depending on the activation of adenosine receptors. Adenosine receptors are classified in terms of their ability to decrease or increase intracellular cAMP concentration. $A_{1}$ and $A_{3}$ receptors are coupled to $G_{i}$ proteins and their stimulation results in decreased intracellular cAMP levels. On the contrary, the stimulation of $\mathrm{A}_{2 \mathrm{~A}}$ and $\mathrm{A}_{2 \mathrm{~B}}$ receptors increases cAMP levels via Gs proteins [134,135]. Methylxanthines are able to inhibit all four subtypes of adenosine receptors $\left(A_{1}, A_{2 A}, A_{2 B}\right.$ and $\left.A_{3}\right)$, but most of their action is thought to be mediated by inhibition of $\mathrm{A}_{1}$ and $\mathrm{A}_{2 \mathrm{~A}}$ receptor types (inhibition in the $\mu \mathrm{M}$ range) [11].

The structure-activity relationships for methylxanthines in their antagonism of adenosine have been first studied by Green and Stanberry in the late 70s [136]. These authors demonstrated that the 1-methyl group is pivotal for the inhibitory effects exerted at the adenosine receptor level (increases activity from none to measurable) and interpreted their results on the basis of the antagonism being allosteric rather than competitive in nature. Both caffeine and theophylline are potent inhibitors of adenosine receptors in the human brain. However, theophylline and paraxanthine were proposed to have slightly higher affinities than caffeine for the adenosine $\mathrm{A}_{1}, \mathrm{~A}_{2 \mathrm{~A}}$, and $\mathrm{A}_{2 \mathrm{~B}}$ receptors [137-140], and to also be weak antagonists for the adenosine $A_{3}$ receptor subtype $[19,141]$. While the action of different methylxanthines are not so dissimilar in the case of adenosine receptors of the $A_{1}$ subtype [142], their inhibitory potency is much more diverse in receptors of the $A_{2}$ subtype $\left(A_{2 A}\right.$ plus $\mathrm{A}_{2 \mathrm{~B}}$ ). $\mathrm{IC}_{50}$ values for effective blockade of receptors of the $\mathrm{A}_{2}$ subtype were 45 and $98 \mu \mathrm{M}$ for theophylline and caffeine respectively, and $2500 \mu \mathrm{M}$ for theobromine [143]. Theobromine (not possessing the 1-methyl group reported as important for adenosine antagonism) was in fact reported to have significantly lower affinity than caffeine for $A_{1}$ and $A_{2 A}$ receptor subtypes [11,144-146].

Despite all the structure-activity variables possible for the interaction between methylxanthines and adenosine receptors, potent and selective antagonists have been developed for all four receptor subtypes based on xanthine structure [147]. Generally, substitutions at position C8 with aryl or cycloalkyl groups has shown promise for identifying novel adenosine $A_{1}$ and $A_{2 A}$ receptor antagonists [148]. Other studies concluded that ethyl substitution at the N1, N3 and N7 positions, when compared to methyl substitutions, seemed to enhance adenosine $A_{1}$ receptor affinity [149].

Because for some people methylxanthine ingestion is almost a chronic matter, it is important to note that such exposure may induce effects that resemble the acute effects of adenosine receptor agonists [150], arising from up-regulation of adenosine receptors $\left(\mathrm{A}_{1}\right.$ and $\left.\mathrm{A}_{2 \mathrm{~A}}\right)$ and adaptive changes leading to adenosine receptor sensitization [150-152].

Methylxanthines may also act as nonselective competitive inhibitors of phosphodiesterases [127,153,154], in particular phosphodiesterase-4 (PDE4) [155,156]. The reversible inhibition of phosphodiesterases compromises the hydrolysis of phosphodiester linkages in different substrate molecules, such as cyclic adenosine cAMP, preventing their degradation and therefore increasing its concentration. In turn, cAMP is an very important second messenger playing fundamental roles in cellular responses to many hormones and neurotransmitters [157].

Several attempts were made to clarify structure-activity relationships of methylxanthines and their potency as phosphodiesterase inhibitors [158]. Caffeine, theobromine and theophylline are all considered relatively weak competitive inhibitors [159]. However, theophylline is supposedly a more potent inhibitor than caffeine [8]. Inhibition of phosphodiesterases was proposed to substantiate the bronchodilator effect of theophylline in asthma treatment [160]. A number of ring-extended xanthines with increased potency (in the nanomolar range) have been developed [161,162]. In fact, structure-activity analyses showed that the methylation at N1 of methylxanthines projects into a small pocket within the phosphodiesterases, and that a pentoxifylline side chain is the largest derivatization fitting that space $[163,164]$.

Regarding the proposed effects of methylxanthines in the modulation of GABA receptors, caffeine [165] and theophylline [166] were both reported to have impact in ion transport by these structures. Later studies specified that caffeine and theophylline act as antagonists or perhaps reverse 
agonists at benzodiazepine sites, while also interacting with the picrotoxinin and GABA sites [167,168]. A group of xanthine derivatives was studied in order to investigate modulatory effects on the binding of ligands to the benzodiazepine and picrotoxinin sites of $\mathrm{GABA}_{\mathrm{A}}$ receptors in mouse cerebral cortical membranes, with caffeine having an $\mathrm{IC}_{50}$ against $\left[{ }^{3} \mathrm{H}\right]$-diazepam of $500 \mu \mathrm{M}$. Two other xanthine derivatives, 1-propargyl-theobromine and 1,3-dipropargyl-7-methylxanthine revealed to be fivefold more potent than caffeine [167].

Methylxanthines were also proposed to stimulate calcium release from intracellular stores, although at relatively high concentrations, through activation of ryanodine-sensitive calcium channels located in the sarcoplasmic reticulum [128,169-172]. In fact, caffeine was described as being a full agonist of the ryanodine receptors, forcing $\mathrm{Ca}^{2+}$ transient fluxes $[167,173,174]$. Studies aiming to clarify structure-activity relationships for the efficacy/potency of xanthines in affecting intracellular or intravesicular calcium indicated that disubstituted xanthines (theophylline, paraxanthine) were ineffective (theobromine) or less effective in intracellular calcium elevation than caffeine [171]. Several semisynthetic methylxanthines, including 1-propyl-3,7-dimethylxanthine and 1-propargyl-3,7-dimethylxanthine [171], or 1,3-dimethyl-7-(7-hydroxyoctyl)xanthine and 3-methyl-7-(7-oxooctyl)-1-propargylxanthine [175], were shown to be more potent than caffeine.

From the four mechanisms of action more commonly proposed for methylxanthine physiologic activity, adenosine receptor antagonism should the one with more in vivo relevance $[11,159,176]$. In fact, methylxanthine plasma concentrations reached through dietary intake should not have effective impact in the activity of phosphodiesterases and GABA $_{A}$ receptors, or calcium release $[11,159,177]$. At physiological doses $(<100 \mu \mathrm{M})$ methylxanthines should only be able to act as non-specific adenosine receptor antagonists [11,178], and only at pharmacological doses (in the mM range) would they increase cellular cAMP via inhibition of phosphodiesterases, PDE4 in particular [154,179-181]. Only at concentrations exceeding therapeutic levels would methylxanthines interfere with $G_{A B A}$ receptors [11,159]. In summary, methylxanthines are only expected to act as adenosine receptor inhibitors at physiologic concentrations. Other mechanisms of action may also take place, but only in special contexts of methylxanthine supplementation, like the use of methylxanthine-rich supplements or medications [143].

Besides the more commonly proposed mechanisms for the action of methylxanthines, several alternative and/or complementary targets have been more recently disclosed. For instance, inhibitory effects on poly(ADPribose)polymerase-1 (a nuclear enzyme responsible for DNA strand breaks repair) have been proposed, especially by paraxanthine [182]. Also, enzyme assays revealed that methylxanthines are active against human chitinases [183]. Theophylline may activate histone deacetylases at low therapeutic concentrations, especially when their activity is reduced by oxidative stress [184,185], while caffeine may act as a non-competitive inhibitor of acetylcholinesterase [186,187], and has also been reported to be a mild inhibitor of monoamine oxidase B [188].

Interestingly, caffeine, theobromine and theophylline may form non-covalent stacking complexes with ATP [189] and affect DNA and RNA structure [190,191]. The full physiological consequences of these interactions, which should only occur at considerable concentrations anyway, are not clarified yet. Nevertheless, it has been hypothesised that sustained interaction with DNA and RNA after consumption of methylxanthine-containing products may induce or repress gene expression [192].

Methylxanthine activity towards molecular targets is obviously determined by attainable physiological concentrations. Regarding natural methylxanthines pharmacokinetics, they are thought to distribute easily through body fluids, to cross biological membranes and they are metabolized in the liver [193]. Caffeine (and paraxanthine) display shorter half-lives (4.1 and $3.1 \mathrm{~h}$, respectively) than theophylline and theobromine $(6.2$ and $7.2 \mathrm{~h}$ for) as well as higher plasma clearances (2.07 and $2.20 \mathrm{~mL} \cdot \mathrm{min}^{-1} \cdot \mathrm{Kg}^{-1}$, for caffeine and paraxanthine respectively, and 0.93 and $1.20 \mathrm{~mL} \cdot \mathrm{min}^{-1} \cdot \mathrm{Kg}^{-1}$, for theophylline and theobromine) [194]. Theophylline has a lower volume of distribution at steady state $(0.44 \mathrm{~L} / \mathrm{Kg})$ when compared to other methylxanthines (0.63-0.72 L/Kg) [194]. After ingestion, caffeine plasma peak concentration was reported to occur at $29.8 \pm 8.1 \mathrm{~min}$ (after a $5 \mathrm{mg} / \mathrm{Kg}$ oral 
administration) [195]. There are several studies reporting plasma peak concentrations after caffeine ingestion. $10.0 \pm 1.0 \mu \mathrm{g} / \mathrm{mL}$ was attained after a $5 \mathrm{mg} / \mathrm{Kg}$ oral dose [195], another study reported a concentration of $1.3 \mu \mathrm{g} / \mathrm{mL}$ after consumption of about $80 \mathrm{mg}$ of caffeine (a cup of coffee) [196], and concentrations in the same range were reported after $100 \mathrm{mg}$ caffeine consumption [197,198]. For theophylline, plasma peak concentrations were accessed in therapeutic context and pointed values of $8.4 \pm 1.7 \mathrm{mg} / \mathrm{L}$ (after oral ingestion of a $5 \mathrm{mg} / \mathrm{Kg}$ dose) [199] and of $7 \mathrm{mg} / \mathrm{L}$, following administration of a single dose of $250 \mathrm{mg}$ [200]. As for theobromine, studies are scarcer, if we do not establish a relationship with chocolate consumption. However, peak concentrations between 3.7 to $8.2 \mathrm{mg} / \mathrm{L}$ were reported after ingestion of a dose of chocolate containing $240 \mathrm{mg}$ by nursing mothers [201], and a value of $8.05 \mu \mathrm{g} / \mathrm{mL}$ was reported to be attained $2 \mathrm{~h}$ after administration dose of chocolate containing $370 \mathrm{mg}$ of theobromine [202].

\section{Physiological and Health Benefits}

In recent years, increased attention has been brought to the dietary effects of methylxanthines. Increased interest from the scientific community, food industry, regular consumers and media on the potential benefits of the consumption of methylxanthine-containing foods and beverages consubstantiated a significant number of basic research and epidemiologic approaches.

The fact that relevant biological effects have been attributed to methylxanthines, supposedly combined with relatively low toxicity, justified the attention dedicated to these compounds and the study of their potential beneficial impact in many disease contexts. In fact, pharmacological formulations containing methylxanthines have been systematically used in common medicine.

Probably, the more obvious target of methylxanthines would be the nervous system. Caffeine has been used as an analgesic co-adjuvant, while being combined with other common analgesics (paracetamol, ibuprofen or acetylsalicylic acid) $[203,204]$. The anti-inflammatory action of methylxanthines is thought to be related with phosphodiesterase inhibition and/or as a adenosine receptor antagonism mechanisms [205]. However, the most commonly known outcome of methylxanthine consumption (in this case, especially caffeine but not only) would be a psychostimulatory activity [206-208]. Moreover, cognitive benefits have also been related with caffeine in both animal and human studies [209-213].

More recently, the study of methylxanthine consumption within the context of neurodegenerative diseases has gathered considerable attention. It is now, undeniably, one of the fields consubstantiating significant methylxanthine research. In fact, regular consumption of caffeine/coffee has been related with lower incidence of Alzheimer's [214-216] and Parkinson's [217-219] diseases. Antagonism of the adenosine receptors (namely $\mathrm{A}_{1}$ and / or $\mathrm{A}_{2 \mathrm{~A}}$ receptors) was suggested to be the mechanism behind the neuroprotective effects of caffeine $[149,220]$. However, protection against blood-brain barrier dysfunction may represent a supplementary action justifying such beneficial effects [221,222].

Starting with Alzheimer's disease, compelling evidence of caffeine neuroprotective activity was compiled in a number of in vitro and in animal studies. In fact, caffeine administration was shown to reduce brain amyloid- $\beta$-peptide $(A \beta)$ accumulation in transgenic mice models of Alzheimer's disease and in cultured neurons taken from these animals [223-226]. Epidemiologic studies seem to confirm a relationship between regular midlife caffeine/coffee consumption and a decreased risk of developing Alzheimer's disease [214,216,227-230]. However, despite all the clues available, the mechanisms underlying caffeine-instigated neuroprotection within the scope of Alzheimer's disease although very intriguing, remain unfortunately unexplained.

Regarding Parkinson's disease, both animal $[217,231,232]$ and epidemiologic $[218,233-238]$ studies have also hinted a link between midlife coffee/caffeine consumption and lower disease incidence. Anyway, as for Alzheimer's disease, the actual mechanism by which caffeine-induced neuroprotection is manifested remains unclear. Other than Alzheimer's and Parkinson's diseases, caffeine also showed promise in the context of Machado-Joseph disease [239]. Interestingly, it was recently proposed to hold detrimental effects in the scope of Huntington's disease [240]. 
Another context in which methylxanthines have been used with therapeutic purposes are respiratory diseases. Curiously, each of the main natural methylxanthines has been used preferentially and with better results in different pathologic conditions. Caffeine is used in the treatment of apnea of prematurity (and its use recently preferred over theophylline) [241-245]. Caffeine action as a ventilatory stimulant has been mostly assigned to antagonism of adenosine receptors in central respiratory centres [246-251], although inhibition of cAMP-dependent phosphodiesterase-4 in the neonatal carotid body [252] may also be in play. As for theophylline, it was used since the 1920's in asthma treatment [19]. Phosphodiesterase inhibition is thought to be a primary mechanism for the bronchodilatory effects ascribed to methylxanthines [19,253], although adenosine receptor antagonism may also be involved in the therapeutic outcomes of methylxanthines asthma treatment [254,255]. Theophylline was also used for some time in the treatment of chronic obstructive pulmonary disease (COPD), although it was lately substituted in this context by other more efficient compounds [256]. Finally, an antitussive action has been unveiled for theobromine [257], which was linked to inhibition of phosphodiesterase activity and antagonism of adenosine $A_{1}$ receptors $[257,258]$.

Although there have always been concerns regarding the effects of methylxanthines (namely caffeine) on cardiovascular parameters, it is now accepted that moderate caffeine consumption does not impact these functions negatively [133,259]. Methylxanthines were reported to hold vasodilator effects [114] and to improve blood microcirculation [260,261]. These effects are supposedly mediated by cAMP levels increase by inhibition of phosphodiesterase activity [259]. Cardiovascular benefits have in fact been ascribed to methylxanthines, supporting their pharmacological use in the treatment of congestive heart failure and anginal syndrome [262]. Moreover, epidemiologic studies have provided evidence of the cardioprotective actions of methylxanthine-containing beverages, in reducing the risk of coronary heart disease and stroke [263-265]. Interestingly, theobromine (through chocolate consumption) was shown to increase high-density lipoprotein (HDL) cholesterol, while decreasing plasma low-density lipoprotein (LDL) cholesterol [266-271]. This effect is independent of adenosine receptor interference [192] and seems to involve increased levels of apolipoprotein-A-I [271].

Another intriguing field that has motivated interesting methylxanthine research is the field of obesity. Methylxanthines were reported to inhibit the elevation of body fat percentage in the developmental-stage rats [272]. Other reports proposed a lipotropic effect for the three main naturally occurring methylxanthines (caffeine, theophylline, and theobromine) [273], and methylxanthines were in fact described to promote lipolysis in vitro [274-277]. Moreover, caffeine intake was proposed to be inversely linked to body weight increase in humans $[278,279]$.

Methylxanthines, namely theophylline and caffeine, have been known for a long while to display diuretic and natriuretic effects [280,281]. Adenosine receptor blockade [282,283] and phosphodiesterase inhibition were proposed to be mechanisms involved in these effects [284,285].

Another scope in which methylxanthines have been linked to putative beneficial effects is diabetes. Both coffee [286-294] and tea [295,296] regular consumption have been related with decreased type 2 diabetes mellitus incidence. However, caffeine may not be the main bioactive compound present in these beverages that is responsible for such protective effects [294,297,298].

In any case, methylxanthines should be able to actively modulate glucose metabolism [299] since both pancreatic cell insulin secretion [300] and liver glucose output [301] depend on cAMP intracellular levels.

Methylxanthines have also been attributed relevant anti-cancer actions and potential. Caffeine was shown to have the potential to beneficially impact several types of cancer, in a number of studies conducted in animals [302-309] and a number of cancer cell lines [310,311]. Caffeine effects should rely on G0/G1 phase cell cycle arrest in cancer cells [312]. Besides caffeine, also theophylline [313-315] and theobromine [155,316-318] were reported to hold antitumor potential.

Other than a direct antitumoral effect, methylxanthines also display the ability to act as valid synergistic cancer treatments. In fact, they have been medically used as adjuvant treatments, promoting sensitizing effects when administrated along chemo- [319-326] and radiotherapy [327-329] 
treatments. The synergistic actions of methylxanthines when administrated along other conventional cancer treatments is thought to take place primarily by promotion of arrest or abrogation of the cell cycle checkpoints, namely the G2/M checkpoint [330-334], which results in jeopardized damaged-DNA repair.

Fertility (male fertility in specific) is another sphere in which methylxanthine positive outcomes may be anticipated. Caffeine was shown to improve the nutritional support of spermatogenesis by Sertoli cells [335]. Methylxanthines were also reported to hold beneficial effects in sperm $\mathrm{Ca}^{2+}$ transport [336] and in the regulation of cAMP levels, which may correlate with increased motility [337,338]. Methylxanthine containing beverages (namely white tea [339]) and caffeine itself [340], were also reported to be valid additives in the context of sperm storage and in vitro fertilization.

Other than all the aforementioned effects, methylxanthines were also sporadically related with beneficial effects under other contexts. Hepatic (cholestatic liver injury [341] and hepatitis C [342]), kidney (of uric acid nephrolithiasis [343]) and ocular (myopia [344,345]) scopes were also hinted to be positively impacted by methylxanthines, but studies are still scarce and do not justify a proper section for each, at least for now.

\section{Drawbacks and Toxicity}

Despite all the relevant virtues of methylxanthines revealed in the section before, the fact is that some shadows of concern seem to come along with those advantages. Drawbacks, fortunately, seem more circumscribed than promises.

The most pressing concerns about methylxanthine consumption are nowadays related with prenatal exposure. Several studies conducted in animals revealed detrimental methylxanthine actions during pregnancy, related with hindered progeny development [346-348]. As for humans, epidemiologic studies comprising analysis of the effects caffeine/coffee consumption in pregnancy parameters, are not at all coherent, some dismissing concerns [349-353], while others do report detrimental effects in development, risk of miscarriage and malformation incidence [354-358]. Concerns seem legitimate, and methylxanthine consumption in pregnant women should be limited and monitored, especially in more aged future mothers [359].

Another aspect that raises concern about methylxanthines regards male fertility, what somewhat contradicts favourable effects presented in the previous section. Animal studies showed that caffeine, theophylline and theobromine administration may induce testicular atrophy and aspermatogenesis $[360,361]$ though the mechanisms remain unknown.

The toxicity of methylxanthines may greatly vary, depending on the specific compound and the animal in question (Table 4). In rats $\mathrm{LD}_{50} \mathrm{~s}$ are $200 \mathrm{mg} / \mathrm{Kg}$ for caffeine, $206 \mathrm{mg} / \mathrm{Kg}$ for theophylline and $950 \mathrm{mg} / \mathrm{Kg}$ for theobromine [114]. In humans, the values are relatively close to those in rats with $\mathrm{LD}_{50}$ 's of $192 \mathrm{mg} / \mathrm{Kg}$ for caffeine, and $1000 \mathrm{mg} / \mathrm{Kg}$ for theobromine. Human acute toxicity towards methylxanthines is very low. For instance, for caffeine the acute toxic level should be about $10 \mathrm{~g} / \mathrm{day}$, which would be comparable to drinking 100 cups of instant coffee [362]. It is important to notice that, in fact, individuals do vary in their sensitivity to methylxanthines, and some of those fluctuations may be genetically originated [363-365].

Moderate caffeine consumption is nowadays considered a rather safe habit [366,367]. However, caffeine acute toxicity effects related with excessive intake may occur, and are well characterized. Altered respiratory parameters, gastrointestinal disturbances, insomnia, nervousness, headache, tachycardia, arrhythmia, nausea, seizures [133,368], may be elicited by caffeine intoxication. Caffeine death-related reports are unusual, and imply rather significant concentrations [133,369]. As for chronic effects, they may involve dysfunction of the liver, musculature and the gastrointestinal and renal systems $[133,370]$. In more extreme cases, symptoms may include myopathy, hypokalemia, muscular weakness, nausea, vomit, diarrhoea and weight loss [207,371]. Another issue related with caffeine chronic consumption as to do with whether it raises dependence or not. Opinions do vary, but a strong 
argument for those claiming that caffeine does not create dependence is raised by those quoting studies that show that the brain circuitry of dependence are not activated by this methylxanthine [372,373].

Table 4. Comparative acute toxicity of methylxanthine (adapted from [114]).

\begin{tabular}{cccccc}
\hline \multicolumn{7}{c}{ LD $_{\mathbf{5 0}}$ (oral, $\mathbf{~ m g / m L )}$} \\
\hline Man & Rat & Mouse & Dog & Cat \\
\hline Caffeine & $150-200^{\mathrm{a}}$ & 200 & 127 & $145^{\mathrm{b}}$ & $125^{\mathrm{b}}$ \\
Theobromine & 1000 & 950 & $135^{\mathrm{b}}$ & 300 & 200 \\
Theophylline & (no data available) $^{\text {(no }}$ & 206 & 332 & 300 & 700 \\
\hline \multicolumn{7}{c}{ Fatal dose; $^{\mathrm{b}}$ Median lethal dose. }
\end{tabular}

Theophylline is normally considered to have stronger toxic effects than caffeine [370]. Theophylline intoxication may manifest in headache, nausea, vomiting, increased acid secretion and gastroesophageal reflux [19], and even convulsions and cardiac arrhythmias at higher concentrations [8,19]. Theobromine has even higher oral lethal doses than caffeine in humans [143], and studies provide evidence of its general innocuousness [374]. However, it may be rather dangerous to other mammals, the most striking example being dogs [258,375]. Since it is commonly accepted that theobromine is generally harmlessness towards humans, studies focusing on its chronic effects are limited. However, we found a study linking undesirable side-effects (sweating, trembling and severe headaches) to long-term intake of considerable quantities of cocoa products $(\approx 100 \mathrm{~g}$ cocoa powder per day) [376]. As for paraxanthine it is also supposedly to be fairly harmless for humans [32].

\section{Conclusions}

Methylxanthines have been a more or less noticeable part of human diet for centuries now, and the fact that they are pharmacologically active compounds was disclosed at least about a century ago. Since then, a number of molecular targets have been uncovered, revealing an intricate chemistry for methylxanthines at the cellular level. Such a variety of molecular (and physiological) actions, summarized in Table 5, motivated considerable amount of scientific endeavors that led to far-reaching impact on biomedical research. It seems fair to expect that this trend will continue for a while, since promise shown by these compounds in some therapeutic context is irrefutable, and the fact is that there is still a lot to ponder and clarify.

Anyway, and considering what has been exposed before, it seems sensible to consider that the advantages that methylxanthines may represent in human physiology largely surpass possible detrimental effects. Concerns about possible deleterious outcomes in fertility and prenatal exposure should not be dismissed, although other toxicity concerns should only arise from eccentric intake or maybe pharmacological doses. Idiosyncratic variables should also be taken into account, making predicting methylxanthine toxicity more complex. Detrimental effects that may be idiosyncratically defined include sleep disturbances or interference with the metabolism of certain medications. Nevertheless, moderate methylxanthine consumption, from common sources in diet, should still be considered safe, and maybe even convenient, taking into account all current knowledge.

Some of the existing concerns may be overcome with de novo design of new molecules based on the basic methylxanthine structure, more specific and effective in specific contexts, displaying also lower inherent toxicity. This line of thought has already been followed and a number of methylxanthine-derivatives were (and are) being studied in terms of physiologic potency and toxicity. Hopefully, these structure-activity approaches will prove helpful in the design of new selective and effective drugs targeting specific human conditions. The wide range of methylxanthine molecular targets would make this an appealing field of research. The possibility of architecting/disclosing multiple-target-directed compounds, acting at multiple targets, should also be attractive. 
Table 5. Methylxanthine reported molecular targets and their suggested involvement in the therapeutic effects ascribed for these compounds.

\begin{tabular}{|c|c|c|c|}
\hline Molecular Target & Effective Concentrations * & Mediated Therapeutics & $\begin{array}{l}\text { Legitimacy of } \\
\text { Evidence }\end{array}$ \\
\hline Adenosine receptors & $\begin{array}{l}50-55 \mu \mathrm{M} \text { for caffeine, } 14 \mu \mathrm{M} \\
\text { for theophylline [122] }\end{array}$ & $\begin{array}{l}\text { asthma }[254,255], \text { apnea of } \\
\text { prematurity [246-251], } \\
\text { cough }[257,258], \\
\text { diuretic }[282,283,377] \text {, analgesic [204] }\end{array}$ & $\begin{array}{l}\text { from in vitro studies to } \\
\text { clinical trials } \\
\text { (therapeutic effects) }\end{array}$ \\
\hline Phosphodiesterase & $55 \mu \mathrm{M}$ for theophylline [256] & $\begin{array}{l}\text { asthma }[19,253] \text {, chronic obstructive } \\
\text { pulmonary disease [256], apnea of } \\
\text { prematurity [252], cough }[257,258] \text {, } \\
\text { diuretic }[284,285] \text {, chronic } \\
\text { lymphocytic leucemia [313] }\end{array}$ & $\begin{array}{l}\text { from in vitro studies to } \\
\text { clinical trials } \\
\text { (therapeutic effects) }\end{array}$ \\
\hline GABA receptors & $500 \mu \mathrm{M}$ for caffeine [167] & --1-1--1* & in vitro studies \\
\hline $\begin{array}{l}\text { Ryanodine-sensitive } \\
\text { calcium channels }\end{array}$ & $>1 \mathrm{mM}$ for cafeine [170] & --------------- & in vitro studies \\
\hline $\begin{array}{l}\text { Poly(ADPribose) } \\
\text { polymerase-1 }\end{array}$ & $\begin{array}{l}160 \mu \mathrm{M} \text { for theobromine, } \\
195 \mu \mathrm{M} \text { for theophylline and } \\
200 \mu \mathrm{M} \text { for caffeine [182] }\end{array}$ & 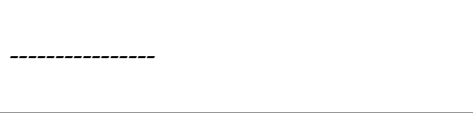 & in vitro studies \\
\hline Chitinases & $\begin{array}{l}469 \mu \mathrm{M} \text { for caffeine and } \\
1.5 \mathrm{mM} \text { theophylline [183] }\end{array}$ & 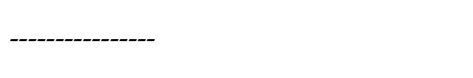 & in vitro studies \\
\hline Histone deacetylases & $24 \mu \mathrm{M}$ for theophylline [184] & asthma, anti-inflammatory [184] & $\begin{array}{l}\text { double-blind crossover } \\
\text { controlled study }\end{array}$ \\
\hline Acetylcholinesterase & $175 \mu \mathrm{M}$ for cafeine [186] & --1-1-1-- & in vitro studies \\
\hline Monoamine oxidase B & $700 \mu \mathrm{M}$ for cafeine $[188]$ & --------------- & in vitro studies \\
\hline
\end{tabular}

It is expectable that methylxanthines remain valid pharmacological tools, by themselves or as adjuvant treatments, and given the promise reported to methylxanthines in some new disease contexts, other applications may emerge. Moreover, the concept of functional foods is evolving and may as well easily incorporate methylxanthines, in the preparation of foods with putative preventive purposes towards some human conditions. Epidemiologic studies should be expanded, and will help circumscribe relevant target populations for future preventive and therapeutic strategies.

Further technologic developments will provide tools to better understanding methylxanthine physiology, as is now being achieved by neuroimaging techniques, and will make this field of research progress and prosper. Hopefully, the subsequent understanding of methylxanthines molecular and physiologic activities will see them achieve the potential anticipated by current knowledge in some particularly concerning conditions.

Acknowledgments: This work was supported by the Portuguese "Fundação para a Ciência e a Tecnologia"—FCT: MGA (SFRH/BPD/80451/2011), PFO (SFRH/BPD/108837/2015), CICS-UBI (PestC/SAU/UI0709/2014) and UMIB (Pest-OE/SAU/UI0215/2014) were co-funded by FEDER via Programa Operacional Fatores de Competitividade-COMPETE/QREN \& FSE and POPH funds.

Conflicts of Interest: The authors declare that there are no conflicts of interest.

\section{Abbreviations}

The following abbreviations are used in this manuscript:

A $\beta \quad$ amyloid- $\beta$-peptide

AMP adenosine monophosphate

cAMP cyclic adenosine monophosphate

CE capillary electrophoresis

CNS central nervous system

COPD chronic obstructive pulmonary disease 


$\begin{array}{ll}\text { GC } & \text { gas chromatography } \\ \text { GC-MS } & \text { gas chromatography-mass spectrometry } \\ \text { GABA } & \text { gamma-aminobutyric acid } \\ \text { GMP } & \text { guanosine monophosphate } \\ \text { HDL } & \text { high-density lipoprotein } \\ \text { HPLC } & \text { high-performance liquid chromatography } \\ \text { LD } 50 & \text { median lethal dose } \\ \text { LDL } & \text { low-density lipoprotein } \\ \text { MRM } & \text { multiple reaction monitoring } \\ \text { MS } & \text { mass spectrometry } \\ \text { PDE } & \text { phosphodiesterase } \\ \text { SAM } & \text { S-adenosyl-L-methionine } \\ \text { TLC } & \text { thin-layer chromatography }\end{array}$

\section{References}

1. Stasolla, C.; Katahira, R.; Thorpe, T.A.; Ashihara, H. Purine and pyrimidine nucleotide metabolism in higher plants. J. Plant Physiol. 2003, 160, 1271-1295. [CrossRef] [PubMed]

2. Zrenner, R.; Stitt, M.; Sonnewald, U.; Boldt, R. Pyrimidine and purine biosynthesis and degradation in plants. Annu. Rev. Plant Biol. 2006, 57, 805-836. [CrossRef] [PubMed]

3. Glantzounis, G.K.; Tsimoyiannis, E.C.; Kappas, A.M.; Galaris, D.A. Uric Acid and Oxidative Stress. Curr. Pharm. Des. 2005, 11, 4145-4151. [CrossRef] [PubMed]

4. Hollingsworth, R.G.; Armstrong, J.W.; Campbell, E. Pest Control: Caffeine as a repellent for slugs and snails. Nature 2002, 417, 915-916. [CrossRef] [PubMed]

5. Frischknecht, P.M.; Ulmer-Dufek, J.; Baumann, T.W. Purine alkaloid formation in buds and developing leaflets of Coffea arabica: Expression of an optimal defence strategy? Phytochemistry 1986, 25, 613-616. [CrossRef]

6. Wolf, A.; Bray, G.A.; Popkin, B.M. A short history of beverages and how our body treats them. Obes. Rev. 2008, 9, 151-164. [CrossRef] [PubMed]

7. Sotelo, A.; Soleri, D.; Wacher, C.; Sánchez-Chinchillas, A.; Argote, R.M. Chemical and nutritional composition of Tejate, a traditional maize and cacao beverage from the central valleys of Oaxaca, Mexico. Plant Foods Hum. Nutr. 2012, 67, 148-155. [CrossRef] [PubMed]

8. Stavric, B. Methylxanthines: Toxicity to humans. 1. Theophylline. Food Chem. Toxicol. 1988, 26, 541-565. [CrossRef]

9. Ashihara, H.; Sano, H.; Crozier, A. Caffeine and related purine alkaloids: Biosynthesis, catabolism, function and genetic engineering. Phytochemistry 2008, 69, 841-856. [CrossRef] [PubMed]

10. Nehlig, A.; Daval, J.-L.; Debry, G. Caffeine and the central nervous system: Mechanisms of action, biochemical, metabolic and psychostimulant effects. Brain Res. Rev. 1992, 17, 139-170. [CrossRef]

11. Fredholm, B.B.; Bättig, K.; Holmén, J.; Nehlig, A.; Zvartau, E.E. Actions of caffeine in the brain with special reference to factors that contribute to its widespread use. Pharmacol. Rev. 1999, 51, 83-133. [PubMed]

12. Jacobson, B.H.; Weber, M.D.; Claypool, L.; Hunt, L.E. Effect of caffeine on maximal strength and power in élite male athletes. Br. J. Sports Med. 1992, 26, 276-280. [CrossRef] [PubMed]

13. Anselme, F.; Collomp, K.; Mercier, B.; Ahmaïdi, S.; Prefaut, C. Caffeine increases maximal anaerobic power and blood lactate concentration. Eur. J. Appl. Physiol. Occup. Physiol. 1992, 65, 188-191. [CrossRef] [PubMed]

14. Jackman, M.; Wendling, P.; Friars, D.; Graham, T.E. Metabolic, catecholamine, and endurance responses to caffeine during intense exercise. J. Appl. Physiol. 1996, 81, 1658-1663. [PubMed]

15. Graham, T.E.; Spriet, L.L. Performance and metabolic responses to a high caffeine dose during prolonged exercise. J. Appl. Physiol. 1991, 71, 2292-2298. [PubMed]

16. Kovacs, E.M.R.; Stegen, J.H.C.H.; Brouns, F. Effect of caffeinated drinks on substrate metabolism, caffeine excretion, and performance. J. Appl. Physiol. 1998, 85, 709-715. [PubMed]

17. Greer, F.; Friars, D.; Graham, T.E. Comparison of caffeine and theophylline ingestion: Exercise metabolism and endurance. J. Appl. Physiol. 2000, 89, 1837-1844. [PubMed]

18. Chapman, R.F.; Mickleborough, T.D. The effects of caffeine on ventilation and pulmonary function during exercise: An often-overlooked response. Phys. Sportsmed. 2009, 37, 97-103. [CrossRef] [PubMed]

19. Barnes, P.J. Theophylline. Am. J. Respir. Crit. Care Med. 2013, 188, 901-906. [CrossRef] [PubMed] 
20. Bell, M.; Jackson, E.; Mi, Z.; McCombs, J.; Carcillo, J. Low-dose theophylline increases urine output in diuretic-dependent critically ill children. Intensive Care Med. 1998, 24, 1099-1105. [CrossRef] [PubMed]

21. Salihović, M.; Huseinović, S.; Špirtović-Halilović, S.; Osmanović, A.; Dedić, A.; Ašimović, Z.; Završnik, D. DFT study and biological activity of some methylxanthines. Bull. Chem. Technol. Bosnia Herzeg. 2014, 42, 31-36.

22. Talik, P.; Krzek, J.; Ekiert, R.J. Analytical techniques used for determination of methylxanthines and their analogues-Recent advances. Sep. Purif. Rev. 2012, 41, 1-61. [CrossRef]

23. McCall, A.L.; Millington, W.R.; Wurtman, R.J. Blood-brain barrier transport of caffeine: Dose-related restriction of adenine transport. Life Sci. 1982, 31, 2709-2715. [CrossRef]

24. Beale, J.M., Jr. Wilson and Gisvold's Textbook of Organic Medicinal and Pharmaceutical Chemistry, 12th ed.; Lippincott Williams \& Wilkins, Wolters Kuwer: Philadelphia, PA, USA, 2011.

25. Pavia, D.L. Coffee, Tea, or Cocoa. A trio of experiments including the isolation of theobromine from cocoa. J. Chem. Educ. 1973, 50, 791. [CrossRef] [PubMed]

26. Gardenhire, D.S. Rau's Respiratory Care Pharmacology, 9th ed.; Elsevier Health Sciences: St. Louis, MO, USA, 2016; p. 140.

27. Ashihara, H.; Suzuki, T. Distribution and biosynthesis of caffeine in plants. Front. Biosci. 2004, 9, $1864-1876$. [CrossRef] [PubMed]

28. Ashihara, H.; Crozier, A. Biosynthesis and metabolism of caffeine and related purine alkaloids in plants. In Advances in Botanical Research; Callow, J.A., Ed.; Academic Press: New York, NY, USA, 1999; Volume 30, pp. 117-205.

29. Mazzafera, P.; Carvalho, A. Breeding for low seed caffeine content of coffee (Coffea L.) by interspecific hybridization. Euphytica 1991, 59, 55-60.

30. Lin, Y.-S.; Tsai, Y.-J.; Tsay, J.-S.; Lin, J.-K. Factors affecting the levels of tea polyphenols and caffeine in tea leaves. J. Agric. Food Chem. 2003, 51, 1864-1873. [CrossRef]

31. Fernandez, P.L.; Martin, M.J.; Gonzalez, A.G.; Pablos, F. HPLC determination of catechins and caffeine in tea. Differentiation of green, black and instant teas. Analyst 2000, 125, 421-425. [CrossRef]

32. Stavric, B. Methylxanthines: Toxicity to humans. 3. Theobromine, paraxanthine and the combined effects of methylxanthines. Food Chem. Toxicol. 1988, 26, 725-733. [CrossRef]

33. Baumann, T.W.; Schulthess, B.H.; Hänni, K. Guaraná (Paullinia cupana) rewards seed dispersers without intoxicating them by caffeine. Phytochemistry 1995, 39, 1063-1070. [CrossRef]

34. Weckerle, C.S.; Stutz, M.A.; Baumann, T.W. Purine alkaloids in Paullinia. Phytochemistry 2003, 64, 735-742. [CrossRef]

35. Kretschmar, J.A.; Baumann, T.W. Caffeine in Citrus flowers. Phytochemistry 1999, 52, 19-23. [CrossRef]

36. Atawodi, S.E.-O.; Pfundstein, B.; Haubner, R.; Spiegelhalder, B.; Bartsch, H.; Owen, R.W. Content of polyphenolic compounds in the nigerian stimulants Cola nitida ssp. alba, Cola nitida ssp. rubra A. Chev, and Cola acuminata Schott \& Endl and their antioxidant capacity. J. Agric. Food Chem. 2007, 55, 9824-9828. [PubMed]

37. Frary, C.D.; Johnson, R.K.; Wang, M.Q. Food sources and intakes of caffeine in the diets of persons in the United States. J. Am. Diet. Assoc. 2005, 105, 110-113. [CrossRef] [PubMed]

38. Gilbert, R.M.; Marshman, J.A.; Schwieder, M.; Berg, R. Caffeine content of beverages as consumed. Can. Med. Assoc. J. 1976, 114, 205-208. [PubMed]

39. Moderno, P.M.; Carvalho, M.; Silva, B.M. Recent patents on Camellia sinensis: Source of health promoting compounds. Recent Pat. Food Nutr. Agric. 2009, 1, 182-192. [CrossRef] [PubMed]

40. Seeram, N.P.; Henning, S.M.; Niu, Y.; Lee, R.; Scheuller, H.S.; Heber, D. Catechin and caffeine content of green tea dietary supplements and correlation with antioxidant capacity. J. Agric. Food Chem. 2006, 54, 1599-1603. [CrossRef] [PubMed]

41. Carvalho, M.; Jerónimo, C.; Valentão, P.; Andrade, P.B.; Silva, B.M. Green tea: A promising anticancer agent for renal cell carcinoma. Food Chem. 2010, 122, 49-54. [CrossRef]

42. Dias, T.R.; Tomás, G.; Teixeira, N.F.; Alves, M.G.; Oliveira, P.F.; Silva, B.M. White tea (Camellia sinensis L.): Antioxidant properties and beneficial health effects. Int. J. Food Sci. Nutr. Diet. 2013, 11, 1-15.

43. Martins, A.D.; Alves, M.G.; Bernardino, R.L.; Dias, T.R.; Silva, B.M.; Oliveira, P.F. Effect of white tea (Camellia sinensis (L.)) extract in the glycolytic profile of Sertoli cell. Eur. J. Nutr. 2013, 53, 1383-1391. [CrossRef] [PubMed] 
44. Unachukwu, U.J.; Ahmed, S.; Kavalier, A.; Lyles, J.T.; Kennelly, E.J. White and green teas (Camellia sinensis var. sinensis): Variation in phenolic, methylxanthine, and antioxidant profiles. J. Food Sci. 2010, 75, C541-C548. [CrossRef] [PubMed]

45. Boros, K.; Jedlinszki, N.; Csupor, D. Theanine and caffeine content of infusions prepared from commercial tea samples. Pharmacogn. Mag. 2016, 12, 75-79. [PubMed]

46. Crozier, T.W.M.; Stalmach, A.; Lean, M.E.J.; Crozier, A. Espresso coffees, caffeine and chlorogenic acid intake: Potential health implications. Food Funct. 2012, 3, 30-33. [CrossRef] [PubMed]

47. McCusker, R.R.; Fuehrlein, B.; Goldberger, B.A.; Gold, M.S.; Cone, E.J. Caffeine content of decaffeinated coffee. J. Anal. Toxicol. 2006, 30, 611-613. [CrossRef] [PubMed]

48. Astill, C.; Birch, M.R.; Dacombe, C.; Humphrey, P.G.; Martin, P.T. Factors affecting the caffeine and polyphenol contents of black and green tea infusions. J. Agric. Food Chem. 2001, 49, 5340-5347. [CrossRef] [PubMed]

49. Blauch, J.L.; Tarka, S.M. HPLC determination of caffeine and theobromine in coffee, tea, and instant hot cocoa Mixes. J. Food Sci. 1983, 48, 745-747. [CrossRef]

50. Bispo, M.S.; Veloso, M.C.C.; Pinheiro, H.L.C.; de Oliveira, R.F.S.; Reis, J.O.N.; de Andrade, J.B. Simultaneous determination of caffeine, theobromine, and theophylline by high-performance liquid chromatography. J. Chromatogr. Sci. 2002, 40, 45-48. [CrossRef] [PubMed]

51. Hicks, M.B.; Hsieh, Y.H.P.; Bell, L.N. Tea preparation and its influence on methylxanthine concentration. Food Res. Int. 1996, 29, 325-330. [CrossRef]

52. Alañón, M.E.; Castle, S.M.; Siswanto, P.J.; Cifuentes-Gómez, T.; Spencer, J.P.E. Assessment of flavanol stereoisomers and caffeine and theobromine content in commercial chocolates. Food Chem. 2016, 208, 177-184. [CrossRef] [PubMed]

53. Cooper, K.A.; Campos-Giménez, E.; Jiménez Alvarez, D.; Rytz, A.; Nagy, K.; Williamson, G. Predictive relationship between polyphenol and nonfat cocoa solids content of chocolate. J. Agric. Food Chem. 2008, 56, 260-265. [CrossRef] [PubMed]

54. Tokusoglu, Ö.; Ünal, K.M. Optimized method for simultaneous determination of catechin, gallic acid, and methylxanthine compounds in chocolate using RP-HPLC. Eur. Food Res. Technol. 2002, 215, 340-346. [CrossRef]

55. Ashihara, H.; Kato, M.; Crozier, A. Distribution, biosynthesis and catabolism of methylxanthines in plants. In Methylxanthines; Springer Berlin Heidelberg: Berlin, Germany; Heidelberg, Germany, 2011; pp. 11-31.

56. Misako, K.; Kouichi, M. Caffeine synthase and related methyltransferases in plants. Front. Biosci. 2004, 9, 1833-1842. [PubMed]

57. Koshiishi, C.; Kato, A.; Yama, S.; Crozier, A.; Ashihara, H. A new caffeine biosynthetic pathway in tea leaves: Utilisation of adenosine released from the S-adenosyl-L-methionine cycle. FEBS Lett. 2001, 499, 50-54. [CrossRef]

58. Zajac, M.A.; Zarkzewski, A.G.; Kowal, M.G.; Narayan, S. A Novel Method of Caffeine Synthesis from Uracil; Taylor \& Francis: Philadelphia, PA, USA, 2003; Volume 33, p. 7.

59. Kumar, N.S.; Chandran, T.B.; Namratha, S.; Bharat, B.R.; Kumar, C.H.P.; Kishore, V. Production of theobromine from Pseudomonas sp. Int. Res. J. Pharm. 2013, 4.

60. Nanjundaiah, S.; Bhatt, P.; Rastogi, N.K.; Thakur, M.S. Response surface optimization for decaffeination and theophylline production by Fusarium solani. Appl. Biochem. Biotechnol. 2015, 178, 58-75. [CrossRef] [PubMed]

61. Begas, E.; Kouvaras, E.; Tsakalof, A.; Papakosta, S.; Asprodini, E.K. In vivo evaluation of CYP1A2, CYP2A6, NAT-2 and xanthine oxidase activities in a Greek population sample by the RP-HPLC monitoring of caffeine metabolic ratios. Biomed. Chromatogr. 2007, 21, 190-200. [CrossRef] [PubMed]

62. El-Yazigi, A.; Shabib, S.; Al-Rawithi, S.; Yusuf, A.; Legayada, E.S.; Al-Humidan, A. Salivary clearance and urinary metabolic pattern of caffeine in healthy children and in pediatric patients with hepatocellular diseases. J. Clin. Pharmacol. 1999, 39, 366-372. [CrossRef] [PubMed]

63. Krul, C.; Hageman, G. Analysis of urinary caffeine metabolites to assess biotransformation enzyme activities by reversed-phase high-performance liquid chromatography. J. Chromatogr. B Biomed. Sci. Appl. 1998, 709, 27-34. [CrossRef]

64. Bendriss, E.-K.; Markoglou, N.; Wainer, I.W. Liquid chromatographic method for the simultaneous determination of caffeine and fourteen caffeine metabolites in urine. J. Chromatogr. B Biomed. Sci. Appl. 2000, 746, 331-338. [CrossRef] 
65. Van Soeren, M.; Mohr, T.; Kjaer, M.; Graham, T.E. Acute effects of caffeine ingestion at rest in humans with impaired epinephrine responses. J. Appl. Physiol. 1996, 80, 999-1005. [PubMed]

66. Newton, R.; Broughton, L.J.; Lind, M.J.; Morrison, P.J.; Rogers, H.J.; Bradbrook, I.D. Plasma and salivary pharmacokinetics of caffeine in man. Eur. J. Clin. Pharmacol. 1981, 21, 45-52. [CrossRef] [PubMed]

67. Georga, K.A.; Samanidou, V.F.; Papadoyannis, I.N. IImproved micro-method for the HPLC analysis of caffeine and its demethylated metabolites in human biological fluids after SPE. J. Liq. Chromatogr. Relat. Technol. 2000, 23, 1523-1537. [CrossRef]

68. Fenske, M. Caffeine determination in human saliva and urine by TLC and ultraviolet absorption densitometry. Chromatographia 2006, 65, 233-238. [CrossRef]

69. Emara, S. Simultaneous determination of caffeine, theophylline and theobromine in human plasma by on-line solid-phase extraction coupled to reversed-phase chromatography. Biomed. Chromatogr. 2004, 18, 479-485. [CrossRef] [PubMed]

70. Setchell, K.D.R.; Beth Welsh, M.; Klooster, M.J.; Balistreri, W.F.; Lim, C.K. Rapid high-performance liquid chromatography assay for salivary and serum caffeine following an oral load. J. Chromatogr. A 1987, 385, 267-274. [CrossRef]

71. Srdjenovic, B.; Djordjevic-Milic, V.; Grujic, N.; Injac, R.; Lepojevic, Z. Simultaneous HPLC determination of caffeine, theobromine, and theophylline in food, drinks, and herbal products. J. Chromatogr. Sci. 2008, 46, 144-149. [CrossRef] [PubMed]

72. González-Nuñez, L.N.; Cañizares-Macías, M.P. Focused microwaves-assisted extraction of theobromine and caffeine from cacao. Food Chem. 2011, 129, 1819-1824. [CrossRef]

73. Saldaña, M.D.A.; Zetzl, C.; Mohamed, R.S.; Brunner, G. Extraction of Methylxanthines from Guaraná Seeds, Maté Leaves, and Cocoa Beans Using Supercritical Carbon Dioxide and Ethanol. J. Agric. Food Chem. 2002, 50, 4820-4826. [CrossRef] [PubMed]

74. Caudle, A.G.; Gu, Y.; Bell, L.N. Improved analysis of theobromine and caffeine in chocolate food products formulated with cocoa powder. Food Res. Int. 2001, 34, 599-603. [CrossRef]

75. Hulbert, G.J.; Biswal, R.N.; Mehr, C.B.; Walker, T.H.; Collins, J.L. Solid/liquid extraction of caffeine from guaraná with methylene chloride/Extracción solido-liquido de cafeina de guarana con cloruro de metileno. Food Sci. Technol. Int. 1998, 4, 53-58. [CrossRef]

76. Belščak, A.; Komes, D.; Horžić, D.; Ganić, K.K.; Karlović, D. Comparative study of commercially available cocoa products in terms of their bioactive composition. Food Res. Int. 2009, 42, 707-716. [CrossRef]

77. Xia, Z.; Ni, Y.; Kokot, S. Simultaneous determination of caffeine, theophylline and theobromine in food samples by a kinetic spectrophotometric method. Food Chem. 2013, 141, 4087-4093. [CrossRef] [PubMed]

78. De Aragão, N.M.; Veloso, M.C.C.; Bispo, M.S.; Ferreira, S.L.C.; de Andrade, J.B. Multivariate optimisation of the experimental conditions for determination of three methylxanthines by reversed-phase high-performance liquid chromatography. Talanta 2005, 67, 1007-1013. [CrossRef] [PubMed]

79. Zacharis, C.K.; Kika, F.S.; Tzanavaras, P.D.; Fytianos, K. Development and validation of a rapid ultra high pressure liquid chromatographic method for the determination of methylxanthines in herbal infusions. J. Chromatogr. B 2013, 927, 218-222. [CrossRef] [PubMed]

80. Hasegawa, T.; Takahashi, K.; Saijo, M.; Ishii, T.; Nagata, T. Rapid determination of theophylline, theobromine and caffeine in dietary supplements containing guarana by ultra-performance liquid chromatography. Shokuhin Eiseigaku Zasshi 2009, 50, 304-310. [CrossRef] [PubMed]

81. Kumazawa, T.; Seno, H.; Lee, X.-P.; Ishii, A.; Watanabe-Suzuki, K.; Sato, K.; Suzuki, O. Extraction of methylxanthines from human body fluids by solid-phase microextraction. Anal. Chim. Acta 1999, 387, 53-60. [CrossRef]

82. Shrivas, K.; Wu, H.-F. Rapid determination of caffeine in one drop of beverages and foods using drop-to-drop solvent microextraction with gas chromatography/mass spectrometry. J. Chromatogr. A 2007, 1170, 9-14. [CrossRef] [PubMed]

83. Tserng, K.Y. Gas chromatographic-mass spectrometric quantitation of theophylline and its metabolites in biological fluids. J. Pharm. Sci. 1983, 72, 526-529. [CrossRef] [PubMed]

84. Khanchi, A.R.; Mahani, M.K.; Hajihosseini, M.; Maragheh, M.G.; Chaloosi, M.; Bani, F. Simultaneous spectrophotometric determination of caffeine and theobromine in Iranian tea by artificial neural networks and its comparison with PLS. Food Chem. 2007, 103, 1062-1068. [CrossRef] 
85. Khoshayand, M.R.; Abdollahi, H.; Shariatpanahi, M.; Saadatfard, A.; Mohammadi, A. Simultaneous spectrophotometric determination of paracetamol, ibuprofen and caffeine in pharmaceuticals by chemometric methods. Spectrochim. Acta Part A Mol. Biomol. Spectrosc. 2008, 70, 491-499. [CrossRef] [PubMed]

86. Singh, D.K.; Sahu, A. Spectrophotometric determination of caffeine and theophylline in pure alkaloids and its application in pharmaceutical formulations. Anal. Biochem. 2006, 349, 176-180. [CrossRef] [PubMed]

87. Armenta, S.; Garrigues, S.; de la Guardia, M. Solid-phase FT-Raman determination of caffeine in energy drinks. Anal. Chim. Acta 2005, 547, 197-203. [CrossRef]

88. Moreira, A.B.; Dias, I.L.T.; Neto, G.O.; Zagatto, E.A.G.; Ferreira, M.M.C.; Kubota, L.T. Solid-phase spectrofluorimetric determination of acetylsalicylic acid and caffeine in pharmaceutical preparations using partial least-squares multivariate calibration. Talanta 2005, 67, 65-69. [CrossRef] [PubMed]

89. Alves, J.C.L.; Poppi, R.J. Simultaneous determination of acetylsalicylic acid, paracetamol and caffeine using solid-phase molecular fluorescence and parallel factor analysis. Anal. Chim. Acta 2009, 642, 212-216. [CrossRef] [PubMed]

90. Paradkar, M.M.; Irudayaraj, J. Rapid determination of caffeine content in soft drinks using FTIR-ATR spectroscopy. Food Chem. 2002, 78, 261-266. [CrossRef]

91. Meinhart, A.D.; Bizzotto, C.S.; Ballus, C.A.; Prado, M.A.; Bruns, R.E.; Filho, J.T.; Godoy, H.T. Optimisation of a CE method for caffeine analysis in decaffeinated coffee. Food Chem. 2010, 120, 1155-1161. [CrossRef]

92. Dilek Uysal, U.; Aturki, Z.; Raggi, M.A.; Fanali, S. Separation of catechins and methylxanthines in tea samples by capillary electrochromatography. J. Sep. Sci. 2009, 32, 1002-1010. [CrossRef] [PubMed]

93. Horie, H.; Mukai, T.; Kohata, K. Simultaneous determination of qualitatively important components in green tea infusions using capillary electrophoresis. J. Chromatogr. A 1997, 758, 332-335. [CrossRef]

94. Thormann, W.; Minger, A.; Molteni, S.; Caslavska, J.; Gebauer, P. Determination of substituted purines in body fluids by micellar electrokinetic capillary chromatography with direct sample injection. J. Chromatogr. 1992, 593, 275-288. [CrossRef]

95. Zhao, Y.; Lunte, C.E. Determination of caffeine and its metabolites by micellar electrokinetic capillary electrophoresis. J. Chromatogr. B Biomed. Sci. Appl. 1997, 688, 265-274. [CrossRef]

96. Bonoli, M.; Colabufalo, P.; Pelillo, M.; Gallina Toschi, T.; Lercker, G. Fast determination of catechins and xanthines in tea beverages by micellar electrokinetic chromatography. J. Agric. Food Chem. 2003, 51, 1141-1147. [CrossRef] [PubMed]

97. Sanghavi, B.J.; Srivastava, A.K. Simultaneous voltammetric determination of acetaminophen, aspirin and caffeine using an in situ surfactant-modified multiwalled carbon nanotube paste electrode. Electrochim. Acta 2010, 55, 8638-8648. [CrossRef]

98. Yang, S.; Yang, R.; Li, G.; Qu, L.; Li, J.; Yu, L. Nafion/multi-wall carbon nanotubes composite film coated glassy carbon electrode for sensitive determination of caffeine. J. Electroanal. Chem. 2010, 639, 77-82. [CrossRef]

99. Cook, C.E.; Tallent, C.R.; Amerson, E.W.; Myers, M.W.; Kepler, J.A.; Taylor, G.F.; Christensen, H.D. Caffeine in plasma and saliva by a radioimmunoassay procedure. J. Pharmacol. Exp. Ther. 1976, 199, 679-686. [PubMed]

100. Van Aerde, P.; Moerman, E.; Van Severen, R.; Braeckman, P. Determination of plasma theophylline by straight-phase high-performance liquid chromatography: Elimination of interfering caffeine metabolites. J. Chromatogr. 1981, 222, 467-474. [CrossRef]

101. Aranda, M.; Morlock, G. Simultaneous determination of caffeine, ergotamine, and metamizol in solid pharmaceutical formulation by HPTLC-UV-FLD with mass confirmation by online HPTLC-ESI-MS. J. Chromatogr. Sci. 2007, 45, 251-255. [CrossRef] [PubMed]

102. Ford, M.J.; Deibel, M.A.; Tomkins, B.A.; van Berkel, G.J. Quantitative thin-layer chromatography/mass spectrometry analysis of caffeine using a surface sampling probe electrospray ionization tandem mass spectrometry system. Anal. Chem. 2005, 77, 4385-4389. [CrossRef] [PubMed]

103. Khasanov, V.V.; Dychko, K.A.; Kuryaeva, T.T.; Ryzhova, G.L.; Mal'tseva, E.V. A new procedure for caffeine determination. Russ. J. Appl. Chem. 2005, 78, 1427-1429. [CrossRef]

104. Llorent-Martínez, E.J.; García-Reyes, J.F.; Ortega-Barrales, P.; Molina-Díaz, A. Solid-phase ultraviolet sensing system for determination of methylxanthines. Anal. Bioanal. Chem. 2005, 382, 158-163. [CrossRef] [PubMed]

105. Adams, R.F.; Vandemark, F.L.; Schmidt, G.J. More sensitive high-pressure liquid-chromatographic determiantion of theophylline in serum. Clin. Chem. 1976, 22, 1903-1906. [PubMed] 
106. Meyer, A.; Ngiruwonsanga, T.; Henze, G. Determination of adenine, caffeine, theophylline and theobromine by HPLC with amperometric detection. Anal. Bioanal. Chem. 1996, 356, 284-287. [CrossRef] [PubMed]

107. Zhu, X.; Chen, B.; Ma, M.; Luo, X.; Zhang, F.; Yao, S.; Wan, Z.; Yang, D.; Hang, H. Simultaneous analysis of theanine, chlorogenic acid, purine alkaloids and catechins in tea samples with the help of multi-dimension information of on-line high performance liquid chromatography/electrospray-mass spectrometry. J. Pharm. Biomed. Anal. 2004, 34, 695-704. [CrossRef]

108. Marchei, E.; Pellegrini, M.; Pacifici, R.; Palmi, I.; Pichini, S. Development and validation of a high-performance liquid chromatography-mass spectrometry assay for methylxanthines and taurine in dietary supplements. J. Pharm. Biomed. Anal. 2005, 37, 499-507. [CrossRef] [PubMed]

109. Ptolemy, A.S.; Tzioumis, E.; Thomke, A.; Rifai, S.; Kellogg, M. Quantification of theobromine and caffeine in saliva, plasma and urine via liquid chromatography-tandem mass spectrometry: A single analytical protocol applicable to cocoa intervention studies. J. Chromatogr. B 2010, 878, 409-416. [CrossRef] [PubMed]

110. Huck, C.W.; Guggenbichler, W.; Bonn, G.K. Analysis of caffeine, theobromine and theophylline in coffee by near infrared spectroscopy (NIRS) compared to high-performance liquid chromatography (HPLC) coupled to mass spectrometry. Anal. Chim. Acta 2005, 538, 195-203. [CrossRef]

111. Bech, B.H.; Bossi, R. Simultaneous determination of methylxanthines and cotinine in human plasma by solid-phase extraction followed by LC-MS-MS. Spectroscopy 2015, 27, 31-34.

112. Rail, T.W. Central nervous system stimulants, the xanthines. In In The Pharmacologic Basis of Therapeutics, 6th ed.; Gilman, L.G.A., Ed.; Macmillan: Toronto, ON, Canada, 1980; p. 592.

113. Moffat, A. Clarke's 'Isolation and Identification of Drugs' (2nd edition) Senior consulting editor: A.C. Moffat Reviewed by I A Blair. J. Pharm. Pharmacol. 1986, 38, 942-944.

114. Tarka, S.M.; Cornish, H.H. The toxicology of cocoa and methylxanthines: A review of the literature. CRC Crit. Rev. Toxicol. 1982, 9, 275-312. [CrossRef]

115. Testa, B. Purine receptors and heir pharmacological roles. In Advances in Drug Research; Jovanovic, H.B., Ed.; Academic Press: London, UK, 1989; Volume 18, pp. 292-430.

116. Mueller, C.E.; Shi, D.; Manning, M.; Daly, J.W. Synthesis of paraxanthine analogs (1,7-disubstituted xanthines) and other xanthines unsubstituted at the 3-position: Structure-activity relationships at adenosine receptors. J. Med. Chem. 1993, 36, 3341-3349. [CrossRef]

117. Miyamoto, K.-I.; Sakai, R.; Yamamoto, Y.; Konno, K.; Sanae, F.; Hasegawa, T.; Takagi, K. Selective Bronchodilators from 1-(5'-Oxohexyl)xanthines. J. Pharm. Pharmacol. 1992, 44, 888-892. [CrossRef] [PubMed]

118. Takagi, K.; Hasegawa, T.; Kuzuya, T.; Ogawa, K.; Watanabe, T.; Satake, T.; Miyamoto, K.; Wakusawa, S.; Koshiura, R. Structure-activity relationship in N3-alkyl-xanthine derivatives. Jpn. J. Pharmacol. 1988, 46, 373-378. [CrossRef] [PubMed]

119. Ali, H.; Müller, C.E.; Daly, J.W.; Beaven, M.A. Methylxanthines block antigen-induced responses in RBL-2H3 cells independently of adenosine receptors or cyclic AMP: Evidence for inhibition of antigen binding to IgE. J. Pharmacol. Exp. Ther. 1991, 258, 954-962. [PubMed]

120. Bruns, R.F. Adenosine antagonism by purines, pteridines and benzopteridines in human fibroblasts. Biochem. Pharmacol. 1981, 30, 325-333. [CrossRef]

121. Bruns, R.F.; Daly, J.W.; Snyder, S.H. Adenosine receptor binding: Structure-activity analysis generates extremely potent xanthine antagonists. Proc. Natl. Acad. Sci. USA 1983, 80, 2077-2080. [CrossRef] [PubMed]

122. Daly, J.W.; Padgett, W.; Shamim, M.T.; Butts-Lamb, P.; Waters, J. 1,3-Dialkyl-8-( $p$-sulfophenyl)xanthines: Potent water-soluble antagonists for $\mathrm{A}_{1}$ - and $\mathrm{A}_{2}$-adenosine receptors. J. Med. Chem. 1985, 28, 487-492. [CrossRef] [PubMed]

123. León-Carmona, J.R.; Galano, A. Is caffeine a good scavenger of oxygenated free radicals? J. Phys. Chem. B 2011, 115, 4538-4546. [CrossRef] [PubMed]

124. Grucka-Mamczar, E.; Zalejska-Fiolka, J.; Chlubek, D.; Kasperczyk, S.; Blaszczyk, U.; Kasperczyk, A.; Swietochowska, E.; Birkner, E. The influence of sodium fluoride and caffeine on the activity of antioxidative enzymes and the concentration of malondialdehyde in rat liver. Fluoride 2009, 42, 105-109.

125. Ofluoglu, E.; Pasaoglu, H.; Pasaoglu, A. The effects of caffeine on L-arginine metabolism in the brain of rats. Neurochem. Res. 2008, 34, 395-399. [CrossRef] [PubMed]

126. Azam, S.; Hadi, N.; Khan, N.U.; Hadi, S.M. Antioxidant and prooxidant properties of caffeine, theobromine and xanthine. Med. Sci. Monit. Int. Med. J. Exp. Clin. Res. 2003, 9, BR325-BR330. 
127. Choi, O.H.; Shamim, M.T.; Padgett, W.L.; Daly, J.W. Caffeine and theophylline analogues: Correlation of behavioral effects with activity as adenosine receptor antagonists and as phosphodiesterase inhibitors. Life Sci. 1988, 43, 387-398. [CrossRef]

128. McPherson, P.S.; Kim, Y.-K.; Valdivia, H.; Knudson, C.M.; Takekura, H.; Franzini-Armstrong, C.; Coronadot, R.; Campbell, K.P. The brain ryanodine receptor: A caffeine-sensitive calcium release channel. Neuron 1991, 7, 17-25. [CrossRef]

129. Chen, J.-F.; Chern, Y. Impacts of methylxanthines and adenosine receptors on neurodegeneration: Human and experimental studies. In Methylxanthines; Springer: Berlin/Heidelberg, Germany, 2011; pp. 267-310.

130. Tazzeo, T.; Bates, G.; Roman, H.N.; Lauzon, A.-M.; Khasnis, M.D.; Eto, M.; Janssen, L.J. Caffeine relaxes smooth muscle through actin depolymerization. Am. J. Physiol. Lung Cell. Mol. Physiol. 2012, 303, L334-L342. [CrossRef] [PubMed]

131. Dent, G.; Giembycz, M.A.; Rabe, K.F.; Wolf, B.; Barnes, P.J.; Magnussen, H. Theophylline suppresses human alveolar macrophage respiratory burst through phosphodiesterase inhibition. Am. J. Respir. Cell Mol. Biol. 1994, 10, 565-572. [CrossRef] [PubMed]

132. Liu, W.; Meissner, G. Structure-activity relationship of xanthines and skeletal muscle ryanodine receptor $/ \mathrm{Ca}^{2+}$ release channel. Pharmacology 1997, 54, 135-143. [CrossRef] [PubMed]

133. Nawrot, P.; Jordan, S.; Eastwood, J.; Rotstein, J.; Hugenholtz, A.; Feeley, M. Effects of caffeine on human health. Food Addit. Contam. 2003, 20,1-30. [CrossRef] [PubMed]

134. Fredholm, B.B.; IJzerman, A.P.; Jacobson, K.A.; Klotz, K.-N.; Linden, J. International Union of Pharmacology. XXV. Nomenclature and classification of adenosine receptors. Pharmacol. Rev. 2001, 53, 527-552. [PubMed]

135. Olah, M.E.; Stiles, G.L. Adenosine receptor subtypes: Characterization and therapeutic regulation. Annu. Rev. Pharmacol. Toxicol. 1995, 35, 581-606. [CrossRef] [PubMed]

136. Green, R.D.; Stanberry, L.R. Elevation of cyclic amp in C-1300 murine neuroblastoma by adenosine and related compounds and the antagonism of this response by methylxanthines. Biochem. Pharmacol. 1977, 26, 37-43. [CrossRef]

137. Boulenger, J.P.; Patel, J.; Marangos, P.J. Effects of caffeine and theophylline on adenosine and benzodiazepine receptors in human brain. Neurosci. Lett. 1982, 30, 161-166. [CrossRef]

138. Fredholm, B.B.; Irenius, E.; Kull, B.; Schulte, G. Comparison of the potency of adenosine as an agonist at human adenosine receptors expressed in Chinese hamster ovary cells. Biochem. Pharmacol. 2001, 61, 443-448. [CrossRef]

139. Klotz, K.-N.; Hessling, J.; Hegler, J.; Owman, C.; Kull, B.; Fredholm, B.B.; Lohse, J.M. Comparative pharmacology of human adenosine receptor subtypes-Characterization of stably transfected receptors in CHO cells. Naunyn Schmiedeberg's Arch. Pharmacol. 1997, 357, 1-9. [CrossRef]

140. Daly, J.W.; Butts-Lamb, P.; Padgett, W. Subclasses of adenosine receptors in the central nervous system: Interaction with caffeine and related methylxanthines. Cell. Mol. Neurobiol. 1983, 3, 69-80. [CrossRef] [PubMed]

141. Baraldi, P.G.; Cacciari, B.; Romagnoli, R.; Merighi, S.; Varani, K.; Borea, P.A.; Spalluto, G. A $A_{3}$ adenosine receptor ligands: History and perspectives. Med. Res. Rev. 2000, 20, 103-128. [CrossRef]

142. Fredholm, B.B.; Persson, C.G.A. Xanthine derivatives as adenosine receptor antagonists. Eur. J. Pharmacol. 1982, 81, 673-676. [CrossRef]

143. Franco, R.; Oñatibia-Astibia, A.; Martínez-Pinilla, E. Health benefits of methylxanthines in cacao and chocolate. Nutrients 2013, 5, 4159-4173. [CrossRef] [PubMed]

144. Shi, D.; Daly, J.W. Chronic effects of xanthines on levels of central receptors in mice. Cell. Mol. Neurobiol. 1999, 19, 719-732. [CrossRef] [PubMed]

145. Carney, J.M.; Holloway, F.A.; Modrow, H.E. Discriminative stimulus properties of methylxanthines and their metabolites in rats. Life Sci. 1985, 36, 913-920. [CrossRef]

146. Schwabe, U.; Ukena, D.; Lohse, M.J. Xanthine derivatives as antagonists at $\mathrm{A}_{1}$ and $\mathrm{A}_{2}$ adenosine receptors. Naunyn Schmiedeberg Arch. Pharmacol. 1985, 330, 212-221. [CrossRef]

147. Moro, S.; Gao, Z.-G.; Jacobson, K.A.; Spalluto, G. Progress in the pursuit of therapeutic adenosine receptor antagonists. Med. Res. Rev. 2006, 26, 131-159. [CrossRef] [PubMed]

148. Baraldi, P.G.; Fruttarolo, F.; Tabrizi, M.A.; Romagnoli, R.; Preti, D. Novel 8-heterocyclyl xanthine derivatives in drug development-An update. Expert Opin. Drug Discov. 2007, 2, 1161-1183. [CrossRef] [PubMed] 
149. Van der Walt, M.M.; Terre'Blanche, G. 1,3,7-Triethyl-substituted xanthines-Possess nanomolar affinity for the adenosine $\mathrm{A}_{1}$ receptor. Bioorg. Med. Chem. 2015, 23, 6641-6649. [CrossRef] [PubMed]

150. Jacobson, K.A.; von Lubitz, D.K.J.E.; Daly, J.W.; Fredholm, B.B. Adenosine receptor ligands: Differences with acute versus chronic treatment. Trends Pharmacol. Sci. 1996, 17, 108-113. [CrossRef]

151. Varani, K.; Portaluppi, F.; Merighi, S.; Ongini, E.; Belardinelli, L.; Borea, P.A. Caffeine alters $A_{2 A}$ adenosine receptors and their function in human platelets. Circulation 1999, 99, 2499-2502. [CrossRef] [PubMed]

152. Biaggioni, I.; Paul, S.; Puckett, A.; Arzubiaga, C. Caffeine and theophylline as adenosine receptor antagonists in humans. J. Pharmacol. Exp. Ther. 1991, 258, 588-593. [PubMed]

153. Herman, A.; Herman, A.P. Caffeine's mechanisms of action and its cosmetic use. Skin Pharmacol. Physiol. 2013, 26, 8-14. [CrossRef] [PubMed]

154. Beavo, J.A.; Rogers, N.L.; Crofford, O.B.; Hardman, J.G.; Sutherland, E.W.; Newman, E.V. Effects of xanthine derivatives on lipolysis and on adenosine $3^{\prime}, 5^{\prime}$-monophosphate phosphodiesterase activity. Mol. Pharmacol. 1970, 6, 597-603. [PubMed]

155. Sugimoto, N.; Miwa, S.; Hitomi, Y.; Nakamura, H.; Tsuchiya, H.; Yachie, A. Theobromine, the primary methylxanthine found in Theobroma cacao, prevents malignant glioblastoma proliferation by negatively regulating phosphodiesterase-4, extracellular signal-regulated kinase, Akt/mammalian target of rapamycin kinase, and nuclear factor-кB. Nutr. Cancer 2014, 66, 419-423. [PubMed]

156. Ruangkittisakul, A.; Ballanyi, K. Methylxanthine reversal of opioid-evoked inspiratory depression via phosphodiesterase-4 blockade. Respir. Physiol. Neurobiol. 2010, 172, 94-105. [CrossRef] [PubMed]

157. Sassone-Corsi, P. The cyclic AMP pathway. Cold Spring Harb. Perspect. Biol. 2012, 4. [CrossRef] [PubMed]

158. Francis, S.H.; Sekhar, K.R.; Ke, H.; Corbin, J.D. Inhibition of cyclic nucleotide phosphodiesterases by methylxanthines and related compounds. In Methylxanthines; Springer: Berlin/Heidelberg, Germany, 2011; pp. 93-133.

159. Daly, J.W. Caffeine analogs: Biomedical impact. Cell. Mol. Life Sci. 2007, 64, 2153-2169. [CrossRef] [PubMed]

160. Rabe, K.; Magnussen, H.; Dent, G. Theophylline and selective PDE inhibitors as bronchodilators and smooth muscle relaxants. Eur. Respir. J. 1995, 8, 637-642. [PubMed]

161. Pissarnitski, D.A.; Asberom, T.; Boyle, C.D.; Chackalamannil, S.; Chintala, M.; Clader, J.W.; Greenlee, W.J.; $\mathrm{Hu}, \mathrm{Y}$;; Kurowski, S.; Myers, J.; et al. SAR development of polycyclic guanine derivatives targeted to the discovery of a selective PDE5 inhibitor for treatment of erectile dysfunction. Bioorg. Med. Chem. Lett. 2004, 14, 1291-1294. [CrossRef] [PubMed]

162. Arnold, R.; Beer, D.; Bhalay, G.; Baettig, U.; Collingwood, S.P.; Craig, S.; Devereux, N.; Dunstan, A.; Glen, A.; Gomez, S.; et al. 8-Aryl xanthines potent inhibitors of phosphodiesterase 5. Bioorg. Med. Chem. Lett. 2002, 12, 2587-2590. [CrossRef]

163. Huai, Q.; Liu, Y.; Francis, S.H.; Corbin, J.D.; Ke, H. Crystal structures of phosphodiesterases 4 and 5 in complex with inhibitor 3-isobutyl-1-methylxanthine suggest a conformation determinant of inhibitor selectivity. J. Biol. Chem. 2004, 279, 13095-13101. [CrossRef] [PubMed]

164. Scapin, G.; Patel, S.B.; Chung, C.; Varnerin, J.P.; Edmondson, S.D.; Mastracchio, A.; Parmee, E.R.; Singh, S.B.; Becker, J.W.; van der Ploeg, L.H.T.; et al. Crystal structure of human phosphodiesterase 3B: Atomic basis for substrate and inhibitor specificity. Biochemistry 2004, 43, 6091-6100. [CrossRef] [PubMed]

165. Lopez, F.; Miller, L.G.; Greenblatt, D.J.; Kaplan, G.B.; Shader, R.I. Interaction of caffeine with the GABAA receptor complex: Alterations in receptor function but not ligand binding. Eur. J. Pharmacol. Mol. Pharmacol. 1989, 172, 453-459. [CrossRef]

166. Sugimoto, T.; Sugimoto, M.; Uchida, I.; Mashimo, T.; Okada, S. Inhibitory effect of theophylline on recombinant GABAA receptor. Neuro Rep. 2001, 12, 489-493. [CrossRef]

167. Shi, D.; Padgett, W.L.; Daly, J.W. Caffeine analogs: Effects on ryanodine-sensitive calcium-release channels and GABAA receptors. Cell. Mol. Neurobiol. 2003, 23, 331-347. [CrossRef] [PubMed]

168. Roca, D.J.; Schiller, G.D.; Farb, D.H. Chronic caffeine or theophylline exposure reduces $\gamma$-aminobutyric acid/benzodiazepine receptor site interactions. Mol. Pharmacol. 1988, 33, 481-485. [PubMed]

169. Daly, J.W. Alkylxanthines as research tools. J. Auton. Nerv. Syst. 2000, 81, 44-52. [CrossRef]

170. Gaburjakova, J.; Gaburjakova, M. Coupled gating modifies the regulation of cardiac ryanodine receptors by luminal $\mathrm{Ca}^{2+}$. Biochim. Biophys. Acta BBA Biomembr. 2014, 1838, 867-873. [CrossRef] [PubMed]

171. Müller, C.E.; Daly, J.W. Stimulation of calcium release by caffeine analogs in pheochromocytoma cells. Biochem. Pharmacol. 1993, 46, 1825-1829. [CrossRef] 
172. Rousseau, E.; Ladine, J.; Liu, Q.-Y.; Meissner, G. Activation of the $\mathrm{Ca}^{2+}$ release channel of skeletal muscle sarcoplasmic reticulum by caffeine and related compounds. Arch. Biochem. Biophys. 1988, 267, 75-86. [CrossRef]

173. Shou, Q.; Pan, S.; Tu, J.; Jiang, J.; Ling, Y.; Cai, Y.; Chen, M.; Wang, D. Modulation effect of Smilax glabra flavonoids on ryanodine receptor mediated intracellular $\mathrm{Ca}^{2+}$ release in cardiomyoblast cells. J. Ethnopharmacol. 2013, 150, 389-392. [CrossRef] [PubMed]

174. Kuemmerle, J.F.; Murthy, K.S.; Makhlouf, G.M. Agonist-activated, ryanodine-sensitive, IP3-insensitive Ca ${ }^{2+}$ release channels in longitudinal muscle of intestine. Am. J. Physiol. Cell Physiol. 1994, 266, C1421-C1431.

175. Cavallaro, R.A.; Filocamo, L.; Galuppi, A.; Galione, A.; Brufani, M.; Genazzani, A.A. Potentiation of cADPR-induced $\mathrm{Ca}^{2+}$-release by methylxanthine analogues. J. Med. Chem. 1999, 42, 2527-2534. [CrossRef] [PubMed]

176. Fredholm, B.B. On the mechanism of action of theophylline and caffeine. Acta Medica Scand. 1985, 217, 149-153. [CrossRef]

177. Marangos, P.J.; Paul, S.M.; Parma, A.M.; Goodwin, F.K.; Syapin, P.; Skolnick, P. Purinergic inhibition of diazepam binding to rat brain (in vitro). Life Sci. 1979, 24, 851-857. [CrossRef]

178. Sattin, A.; Rall, T.W. The effect of adenosine and adenine nucleotides on the cyclic adenosine $3^{\prime}, 5^{\prime}$-phosphate content of guinea pig cerebral cortex slices. Mol. Pharmacol. 1970, 6, 13-23. [PubMed]

179. Cardinali, D.P. Methylxanthines: Possible mechanisms of action in brain. Trends Pharmacol. Sci. 1980, 1, 405-407. [CrossRef]

180. Butcher, R.W.; Sutherland, E.W. Adenosine 3',5'-Phosphate in Biological Materials: I. Purification and properties of cyclic $3^{\prime}, 5^{\prime}$-nucleotide phosphodiesterase and use of this enzyme to characterize adenosine 3',5'-phosphate in human urine. J. Biol. Chem. 1962, 237, 1244-1250. [PubMed]

181. Nicholson, C.D.; Jackman, S.A.; Wilke, R. The ability of denbufylline to inhibit cyclic nucleotide phosphodiesterase and its affinity for adenosine receptors and the adenosine re-uptake site. Br. J. Pharmacol. 1989, 97, 889-897. [CrossRef] [PubMed]

182. Geraets, L.; Moonen, H.J.J.; Wouters, E.F.M.; Bast, A.; Hageman, G.J. Caffeine metabolites are inhibitors of the nuclear enzyme poly(ADP-ribose)polymerase-1 at physiological concentrations. Biochem. Pharmacol. 2006, 72, 902-910. [CrossRef] [PubMed]

183. Rao, F.V.; Andersen, O.A.; Vora, K.A.; DeMartino, J.A.; van Aalten, D.M.F. Methylxanthine drugs are chitinase inhibitors: Investigation of inhibition and binding modes. Chem. Biol. 2005, 12, 973-980. [CrossRef] [PubMed]

184. Ito, K.; Lim, S.; Caramori, G.; Cosio, B.; Chung, K.F.; Adcock, I.M.; Barnes, P.J. A molecular mechanism of action of theophylline: Induction of histone deacetylase activity to decrease inflammatory gene expression. Proc. Natl. Acad. Sci. USA 2002, 99, 8921-8926. [CrossRef] [PubMed]

185. Cosio, B.G.; Tsaprouni, L.; Ito, K.; Jazrawi, E.; Adcock, I.M.; Barnes, P.J. Theophylline restores histone deacetylase activity and steroid responses in COPD macrophages. J. Exp. Med. 2004, 200, 689-695. [CrossRef] [PubMed]

186. Pohanka, M.; Dobes, P. Caffeine inhibits acetylcholinesterase, but not butyrylcholinesterase. Int. J. Mol. Sci. 2013, 14, 9873-9882. [CrossRef] [PubMed]

187. Miroslav, P. The effects of caffeine on the cholinergic system. Mini Rev. Med. Chem. 2014, 14, 543-549.

188. Petzer, A.; Pienaar, A.; Petzer, J.P. The interactions of caffeine with monoamine oxidase. Life Sci. 2013, 93, 283-287. [CrossRef] [PubMed]

189. Gattuso, G.; Manfredi, G.; Sammartano, S. Quantitative study on the non-covalent interactions between ATP and caffeine, theophylline and theobromine in aqueous solution. Fluid Phase Equilibria 2011, 308, 47-54. [CrossRef]

190. Johnson, I.M.; Prakash, H.; Prathiba, J.; Raghunathan, R.; Malathi, R. Spectral analysis of naturally occurring methylxanthines (theophylline, theobromine and caffeine) binding with DNA. PLoS ONE 2012, 7, e50019. [CrossRef] [PubMed]

191. Johnson, I.M.; Kumar, S.G.B.; Malathi, R. RNA binding efficacy of theophylline, theobromine and caffeine. J. Biomol. Struct. Dyn. 2003, 20, 687-692. [CrossRef] [PubMed]

192. Martínez-Pinilla, E.; Oñatibia-Astibia, A.; Franco, R. The relevance of theobromine for the beneficial effects of cocoa consumption. Front. Pharmacol. 2015, 6, 1-5. [CrossRef] [PubMed] 
193. Arnaud, M.J. Pharmacokinetics and metabolism of natural methylxanthines in animal and man. In Methylxanthines; Springer: Berlin/Heidelberg, Germany, 2011; pp. 33-91.

194. Lelo, A.; Birkett, D.J.; Robson, R.A.; Miners, J.O. Comparative pharmacokinetics of caffeine and its primary demethylated metabolites paraxanthine, theobromine and theophylline in man. Br. J. Cl. Pharmacol. 1986, 22, 177-182. [CrossRef]

195. Blanchard, J.; Sawers, S.J.A. The absolute bioavailability of caffeine in man. Eur. J. Clin. Pharmacol. 1983, 24, 93-98. [CrossRef] [PubMed]

196. Zandvliet, A.S.; Huitema, A.D.R.; de Jonge, M.E.; den Hoed, R.; Sparidans, R.W.; Hendriks, V.M.; van Den Brink, W.; van Ree, J.M.; Beijnen, J.H. Population pharmacokinetics of caffeine and its metabolites theobromine, paraxanthine and theophylline after inhalation in combination with diacetylmorphine. Basic Clin. Pharmacol. Toxicol. 2005, 96, 71-79. [CrossRef] [PubMed]

197. Teekachunhatean, S.; Tosri, N.; Rojanasthien, N.; Srichairatanakool, S.; Sangdee, C. Pharmacokinetics of caffeine following a single administration of coffee enema versus oral coffee consumption in healthy male subjects. ISRN Pharmacol. 2013, 2013, 7. [CrossRef] [PubMed]

198. Perera, V.; Gross, A.S.; McLachlan, A.J. Caffeine and paraxanthine HPLC assay for CYP1A2 phenotype assessment using saliva and plasma. Biomed. Chromatogr. 2010, 24, 1136-1144. [CrossRef] [PubMed]

199. Becker, A.B.; Simons, K.J.; Gillespie, C.A.; Simons, F.E.R. The bronchodilator effects and pharmacokinetics of caffeine in asthma. N. Engl. J. Med. 1984, 310, 743-746. [CrossRef] [PubMed]

200. French, I.W.; Mildon, C.A. The pharmacokinetics of theophylline. Curr. Med. Res. Opin. 1979, 6 (Suppl. S6), 3-13. [CrossRef]

201. Resman, B.H.; Blumenthal, H.P.; Jusko, W.J. Breast milk distribution of theobromine from chocolate. J. Pediatr. 1977, 91, 477-480. [CrossRef]

202. Mumford, K.G.; Benowitz, L.N.; Evans, M.S.; Kaminski, J.B.; Preston, L.K.; Sannerud, A.C.; Silverman, K.; Griffiths, R.R. Absorption rate of methylxanthines following capsules, cola and chocolate. Eur. J. Clin. Pharmacol. 1996, 51, 319-325. [CrossRef] [PubMed]

203. Laska, E.M.; Sunshine, A.; Mueller, F.; Elvers, W.B.; Siegel, C.; Rubin, A. Caffeine as an analgesic adjuvant. JAMA 1984, 251, 1711-1718. [CrossRef] [PubMed]

204. Derry, C.J.; Derry, S.; Moore, R.A. Caffeine as an analgesic adjuvant for acute pain in adults. Cochrane Database Syst. Rev. 2014, 12, 1-62.

205. Lee, I.-A.; Kamba, A.; Low, D.; Mizoguchi, E. Novel methylxanthine derivative-mediated anti-inflammatory effects in inflammatory bowel disease. World J. Gastroenterol. 2014, 20, 1127-1138. [CrossRef] [PubMed]

206. Beaumont, M.; Batéjat, D.; Coste, O.; Doireau, P.; Chauffard, F.; Enslen, M.; Lagarde, D.; Pierard, C. Recovery after prolonged sleep deprivation: Residual effects of slow-release caffeine on recovery sleep, sleepiness and cognitive functions. Neuropsychobiology 2005, 51, 16-27. [CrossRef] [PubMed]

207. Lozano, R.P.; García, Y.A.; Tafalla, D.B.; Albaladejo, M.F. Cafeína: Un nutriente, un fármaco, o una droga de abuso. Adicciones 2007, 19, 225-238. [CrossRef]

208. Smit, H.J.; Gaffan, E.A.; Rogers, P.J. Methylxanthines are the psycho-pharmacologically active constituents of chocolate. Psychopharmacology 2004, 176, 412-419. [CrossRef] [PubMed]

209. Takahashi, R.N.; Pamplona, F.A.; Prediger, R.D. Adenosine receptor antagonists for cognitive dysfunction: A review of animal studies. Front. Biosci. 2008, 13, 2614-2632. [CrossRef] [PubMed]

210. Angelucci, M.E.M.; Cesário, C.; Hiroi, R.H.; Rosalen, P.L.; Cunha, C.D. Effects of caffeine on learning and memory in rats tested in the Morris water maze. Braz. J. Med. Biol. Res. 2002, 35, 1201-1208. [CrossRef] [PubMed]

211. Lieberman, H.R. The effects of ginseng, ephedrine, and caffeine on cognitive performance, mood and energy. Nutr. Rev. 2001, 59, 91-102. [CrossRef] [PubMed]

212. Haskell, C.F.; Kennedy, D.O.; Wesnes, K.A.; Scholey, A.B. Cognitive and mood improvements of caffeine in habitual consumers and habitual non-consumers of caffeine. Psychopharmacology 2005, 179, 813-825. [CrossRef] [PubMed]

213. Riedel, W.; Hogervorst, E.; Leboux, R.; Verhey, F.; van Praag, H.; Jolles, J. Caffeine attenuates scopolamine-induced memory impairment in humans. Psychopharmacology 1995, 122, 158-168. [CrossRef] [PubMed]

214. Maia, L.; de Mendonça, A. Does caffeine intake protect from Alzheimer's disease? Eur. J. Neurol. 2002, 9, 377-382. [CrossRef] [PubMed] 
215. Arendash, G.W.; Cao, C. Caffeine and coffee as therapeutics against Alzheimer's disease. J. Alzheimers Dis. 2010, 20, S117-S126. [PubMed]

216. Eskelinen, M.H.; Ngandu, T.; Tuomilehto, J.; Soininen, H.; Kivipelto, M. Midlife coffee and tea drinking and the risk of latelife dementia: A population-based CAIDE study. J. Alzheimers Dis. 2009, 16, 85-91. [PubMed]

217. Chen, J.F.; Xu, K.; Petzer, J.P.; Staal, R.; Xu, Y.H.; Beilstein, M.; Sonsalla, P.K.; Castagnoli, K.; Castagnoli, N.J.; Schwarzschild, M.A. Neuroprotection by caffeine and $\mathrm{A}_{2 \mathrm{~A}}$ adenosine receptor inactivation in a model of Parkinson's disease. J. Neurosci. 2001, 21, RC143. [PubMed]

218. Costa, J.; Lunet, N.; Santos, C.; Santos, J.; Vaz-Carneiro, A. Caffeine exposure and the risk of Parkinson's disease: A systematic review and meta-analysis of observational studies. J. Alzheimers Dis. 2010, 20, S221-S238. [PubMed]

219. Postuma, R.B.; Lang, A.E.; Munhoz, R.P.; Charland, K.; Pelletier, A.; Moscovich, M.; Filla, L.; Zanatta, D.; Rios Romenets, S.; Altman, R.; et al. Caffeine for treatment of Parkinson disease: A randomized controlled trial. Neurology 2012, 79, 651-658. [CrossRef] [PubMed]

220. Doré, A.S.; Robertson, N.; Errey, J.C.; Ng, I.; Hollenstein, K.; Tehan, B.; Hurrell, E.; Bennett, K.; Congreve, M.; Magnani, F.; et al. Structure of the adenosine $\mathrm{A}_{2 \mathrm{~A}}$ receptor in complex with ZM241385 and the xanthines XAC and caffeine. Structure 2011, 19, 1283-1293. [CrossRef] [PubMed]

221. Chen, X.; Gawryluk, J.W.; Wagener, J.F.; Ghribi, O.; Geiger, J.D. Caffeine blocks disruption of blood brain barrier in a rabbit model of Alzheimer's disease. J. Neuroinflammation 2008, 5, 12. [CrossRef] [PubMed]

222. Chen, X.; Lan, X.; Roche, I.; Liu, R.; Geiger, J.D. Caffeine protects against MPTP-induced blood-brain barrier dysfunction in mouse striatum. J. Neurochem. 2008, 107, 1147-1157. [CrossRef] [PubMed]

223. Arendash, G.W.; Schleif, W.; Rezai-Zadeh, K.; Jackson, E.K.; Zacharia, L.C.; Cracchiolo, J.R.; Shippy, D.; Tan, J. Caffeine protects Alzheimer's mice against cognitive impairment and reduces brain $\beta$-amyloid production. Neuroscience 2006, 142, 941-952. [CrossRef] [PubMed]

224. Cao, C.; Cirrito, J.R.; Lin, X.; Wang, L.; Verges, D.K.; Dickson, A.; Mamcarz, M.; Zhang, C.; Mori, T.; Arendash, G.W.; et al. Caffeine suppresses $\beta$-amyloid levels in plasma and brain of Alzheimer's transgenic mice. J. Alzheime's Dis. JAD 2009, 17, 681-697. [PubMed]

225. Chu, Y.-F.; Chang, W.-H.; Black, R.M.; Liu, J.-R.; Sompol, P.; Chen, Y.; Wei, H.; Zhao, Q.; Cheng, I.H. Crude caffeine reduces memory impairment and amyloid $\beta 1-42$ levels in an Alzheimer's mouse model. Food Chem. 2012, 135, 2095-2102. [CrossRef] [PubMed]

226. Arendash, G.W.; Mori, T.; Cao, C.; Mamcarz, M.; Runfeldt, M.; Dickson, A.; Rezai-Zadeh, K.; Tane, J.; Citron, B.A.; et al. Caffeine reverses cognitive impairment and decreases brain amyloid-beta levels in aged Alzheimer's disease mice. J. Alzheimers Dis. 2009, 17, 661-680. [PubMed]

227. Lindsay, J.; Laurin, D.; Verreault, R.; Hébert, R.; Helliwell, B.; Hill, G.B.; McDowell, I. Risk factors for Alzheimer's disease: A prospective analysis from the Canadian Study of Health and Aging. Am. J. Epidemiol. 2002, 156, 445-453. [CrossRef] [PubMed]

228. Ritchie, K.; Carrière, I.; de Mendonça, A.; Portet, F.; Dartigues, J.F.; Rouaud, O.; Barberger-Gateau, P.; Ancelin, M.L. The neuroprotective effects of caffeine: A prospective population study (the Three City Study). Neurology 2007, 69, 536-545. [CrossRef] [PubMed]

229. Johnson-Kozlow, M.; Kritz-Silverstein, D.; Barrett-Connor, E.; Morton, D. Coffee consumption and cognitive function among older adults. Am. J. Epidemiol. 2002, 156, 842-850. [CrossRef] [PubMed]

230. Van Gelder, B.M.; Buijsse, B.; Tijhuis, M.; Kalmijn, S.; Giampaoli, S.; Nissinen, A.; Kromhout, D. Coffee consumption is inversely associated with cognitive decline in elderly European men: the FINE Study. Eur. J. Clin. Nutr. 2006, 61, 226-232. [CrossRef] [PubMed]

231. Li, W.; Dai, S.; An, J.; Li, P.; Chen, X.; Xiong, R.; Liu, P.; Wang, H.; Zhao, Y.; Zhu, M.; et al. Chronic but not acute treatment with caffeine attenuates traumatic brain injury in the mouse cortical impact model. Neuroscience 2008, 151, 1198-1207. [CrossRef] [PubMed]

232. Sonsalla, P.K.; Wong, L.-Y.; Harris, S.L.; Richardson, J.R.; Khobahy, I.; Li, W.; Gadad, B.S.; German, D.C. Delayed caffeine treatment prevents nigral dopamine neuron loss in a progressive rat model of Parkinson's disease. Exp. Neurol. 2012, 234, 482-487. [CrossRef] [PubMed]

233. Benedetti, M.D.; Bower, J.H.; Maraganore, D.M.; McDonnell, S.K.; Peterson, B.J.; Ahlskog, J.E.; Schaid, D.J.; Rocca, W.A. Smoking, alcohol, and coffee consumption preceding Parkinson's disease: A case-control study. Neurology 2000, 55, 1350-1358. [CrossRef] [PubMed] 
234. Ross, G.; Abbott, R.D.; Petrovitch, H.; Morens, D.M.; Grandinetti, A.; Tung, K.H.; Tanner, C.M.; Masaki, K.H.; Blanchette, P.L.; Curb, J.D.; et al. Association of coffee and caffeine intake with the risk of parkinson disease. JAMA 2000, 283, 2674-2679. [CrossRef] [PubMed]

235. Saaksjarvi, K.; Knekt, P.; Rissanen, H.; Laaksonen, M.A.; Reunanen, A.; Mannisto, S. Prospective study of coffee consumption and risk of Parkinson's disease. Eur. J. Clin. Nutr. 2007, 62, 908-915. [CrossRef] [PubMed]

236. Ascherio, A.; Zhang, S.M.; Hernán, M.A.; Kawachi, I.; Colditz, G.A.; Speizer, F.E.; Willett, W.C. Prospective study of caffeine consumption and risk of Parkinson's disease in men and women. Ann. Neurol. 2001, 50, 56-63. [CrossRef] [PubMed]

237. Palacios, N.; Gao, X.; McCullough, M.L.; Schwarzschild, M.A.; Shah, R.; Gapstur, S.; Ascherio, A. Caffeine and risk of Parkinson disease in a large cohort of men and women. Mov. Disord. 2012, 27, 1276-1282. [CrossRef] [PubMed]

238. Qi, H.; Li, S. Dose-response meta-analysis on coffee, tea and caffeine consumption with risk of Parkinson's disease. Geriatr. Gerontol. Int. 2014, 14, 430-439. [CrossRef] [PubMed]

239. Gonçalves, N.; Simões, A.T.; Cunha, R.A.; de Almeida, L.P. Caffeine and adenosine $A_{2 A}$ receptor inactivation decrease striatal neuropathology in a lentiviral-based model of Machado-Joseph disease. Ann. Neurol. 2013, 73, 655-666. [CrossRef] [PubMed]

240. Simonin, C.; Duru, C.; Salleron, J.; Hincker, P.; Charles, P.; Delval, A.; Youssov, K.; Burnouf, S.; Azulay, J.-P.; Verny, C.; et al. Association between caffeine intake and age at onset in Huntington's disease. Neurobiol. Dis. 2013, 58, 179-182. [CrossRef] [PubMed]

241. Henderson-Smart, D.J.; De Paoli, A.G. Methylxanthine treatment for apnoea in preterm infants. Cochrane Database Syst. Rev. 2010, 8. [CrossRef]

242. Comer, A.M.; Perry, C.M.; Figgitt, D.P. Caffeine citrate: A review of its use in apnoea of prematurity. Paediatric Drugs 2001, 3, 61-79. [CrossRef] [PubMed]

243. Bhatia, J. Current options in the management of apnea of prematurity. Clin. Pediatr. 2000, 39, 327-336. [CrossRef]

244. Aranda, J.V.; Beharry, K.; Valencia, G.B.; Natarajan, G.; Davis, J. Caffeine impact on neonatal morbidities. J. Matern. Fetal Neonatal Med. 2010, 23 (Suppl. S3), 20-23. [CrossRef] [PubMed]

245. Schoen, K.; Yu, T.; Stockmann, C.; Spigarelli, M.G.; Sherwin, C.M.T. Use of methylxanthine therapies for the treatment and prevention of apnea of prematurity. Pediatr. Drugs 2014, 16, 169-177. [CrossRef] [PubMed]

246. Lagercrantz, H.; Yamamoto, Y.; Fredholm, B.B.; Prabhakar, N.R.; von Euler, C. Adenosine analogues depress ventilation in rabbit neonates. Theophylline stimulation of respiration via adenosine receptors? Pediatr. Res. 1984, 18, 387-390. [CrossRef] [PubMed]

247. Kawai, A.; Okada, Y.; Mückenhoff, K.; Scheid, P. Theophylline and hypoxic ventilatory response in the rat isolated brainstem-spinal cord. Respir. Physiol. 1995, 100, 25-32. [CrossRef]

248. Wennergren, G.; Wennergren, M. Neonatal breathing control mediated via the central chemoreceptors. Acta Physiol. Scand. 1983, 119, 139-146. [CrossRef] [PubMed]

249. Herlenius, E.; Lagercrantz, H. Adenosinergic modulation of respiratory neurones in the neonatal rat brainstem in vitro. J. Physiol. 1999, 518, 159-172. [CrossRef] [PubMed]

250. Eldridge, F.L.; Millhorn, D.E.; Kiley, J.P. Antagonism by theophylline of respiratory inhibition induced by adenosine. J. Appl. Physiol. 1985, 59, 1428-1433. [PubMed]

251. Hedner, T.; Hedner, J.; Bergman, B.; Mueller, R.A.; Jonason, J. Characterization of adenosine-induced respiratory depression in the preterm rabbit. Biol. Neonate 1985, 47, 323-332. [CrossRef] [PubMed]

252. Mosca, E.V.; Ciechanski, P.; Roy, A.; Scheibli, E.C.; Ballanyi, K.; Wilson, R.J.A. Methylxanthine reversal of opioid-induced respiratory depression in the neonatal rat: Mechanism and location of action. Respir. Physiol. Neurobiol. 2014, 200, 80-89. [CrossRef] [PubMed]

253. Barnes, P.J. Theophylline in chronic obstructive pulmonary disease: New horizons. Proc. Am. Thorac. Soc. 2005, 2, 334-339. [CrossRef] [PubMed]

254. Fozard, J.R.; McCarthy, C. Adenosine receptor ligands as potential therapeutics in asthma. Curr. Opin. Investig. Drugs 2002, 3, 69-77. [PubMed]

255. Russo, C.; Arcidiacono, G.; Polosa, R. Adenosine receptors: Promising targets for the development of novel therapeutics and diagnostics for asthma. Fundam. Clin. Pharmacol. 2006, 20, 9-19. [CrossRef] [PubMed]

256. Barnes, P.J. Theophylline for COPD. Thorax 2006, 61, 742-744. [CrossRef] [PubMed] 
257. Usmani, O.S.; Belvisi, M.G.; Patel, H.J.; Crispino, N.; Birrell, M.A.; Korbonits, M.; Korbonits, D.; Barnes, P.J. Theobromine inhibits sensory nerve activation and cough. FASEB J. 2004. [CrossRef] [PubMed]

258. Smit, H.J. Theobromine and the pharmacology of cocoa. In Methylxanthines; Springer: Berlin, Germany; Heidelberg, Germany, 2011; pp. 201-234.

259. Riksen, N.P.; Smits, P.; Rongen, G.A. The cardiovascular effects of methylxanthines. In Methylxanthines; Springer: Berlin, Germany; Heidelberg, Germany, 2011; pp. 413-437.

260. Cameron, O.G.; Modell, J.G.; Hariharan, M. Caffeine and human cerebral blood flow: A positron emission tomography study. Life Sci. 1990, 47, 1141-1146. [CrossRef]

261. Okuno, T.; Sugiyama, T.; Tominaga, M.; Kojima, S.; Ikeda, T. Effects of caffeine on microcirculation of the human ocular fundus. Jpn. J. Ophthalmol. 2002, 46, 170-176. [CrossRef]

262. Batterman, R.G.; Grossman, A.J.; Dubinsky, J.; Mouratoff, G. Reevaluation of the usefullness of theobromine calcium gluconate for the management of congestive heart failure and anginal syndrome. Int. Rec. Med. Gen. Pract. Clin. 1959, 172, 318-323. [PubMed]

263. Larsson, S.C.; Orsini, N. Coffee consumption and risk of stroke: A dose-response meta-analysis of prospective studies. Am. J. Epidemiol. 2011, 174, 993-1001. [CrossRef] [PubMed]

264. Ding, M.; Bhupathiraju, S.N.; Satija, A.; van Dam, R.M.; Hu, F.B. Long-term coffee consumption and risk of cardiovascular disease: A systematic review and a dose-response meta-analysis of prospective cohort studies. Circulation 2014, 129, 643-659. [CrossRef] [PubMed]

265. Bohn, S.K.; Ward, N.C.; Hodgson, J.M.; Croft, K.D. Effects of tea and coffee on cardiovascular disease risk. Food Funct. 2012, 3, 575-591. [CrossRef] [PubMed]

266. Khan, N.; Monagas, M.; Andres-Lacueva, C.; Casas, R.; Urpí-Sardà, M.; Lamuela-Raventós, R.M.; Estruch, R. Regular consumption of cocoa powder with milk increases HDL cholesterol and reduces oxidized LDL levels in subjects at high-risk of cardiovascular disease. Nutr. Metab. Cardiovasc. Dis. 2012, 22, 1046-1053. [CrossRef] [PubMed]

267. Kris-Etherton, P.M.; Derr, J.A.; Mustad, V.A.; Seligson, F.H.; Pearson, T.A. Effects of a milk chocolate bar per day substituted for a high-carbohydrate snack in young men on an NCEP/AHA Step 1 Diet. Am. J. Clin. Nutr. 1994, 60, 1037S-1042S.

268. Mursu, J.; Voutilainen, S.; Nurmi, T.; Rissanen, T.H.; Virtanen, J.K.; Kaikkonen, J.; Nyyssönen, K.; Salonen, J.T. Dark chocolate consumption increases HDL cholesterol concentration and chocolate fatty acids may inhibit lipid peroxidation in healthy humans. Free Radic. Biol. Med. 2004, 37, 1351-1359. [CrossRef] [PubMed]

269. Baba, S.; Osakabe, N.; Kato, Y.; Natsume, M.; Yasuda, A.; Kido, T.; Fukuda, K.; Muto, Y.; Kondo, K. Continuous intake of polyphenolic compounds containing cocoa powder reduces LDL oxidative susceptibility and has beneficial effects on plasma HDL-cholesterol concentrations in humans. Am. J. Clin. Nutr. 2007, 85, 709-717. [PubMed]

270. Mellor, D.D.; Sathyapalan, T.; Kilpatrick, E.S.; Beckett, S.; Atkin, S.L. High-cocoa polyphenol-rich chocolate improves HDL cholesterol in Type 2 diabetes patients. Diabet. Med. 2010, 27, 1318-1321. [CrossRef] [PubMed]

271. Neufingerl, N.; Zebregs, Y.E.; Schuring, E.A.; Trautwein, E.A. Effect of cocoa and theobromine consumption on serum HDL-cholesterol concentrations: A randomized controlled trial. Am. J. Clin. Nutr. 2013, 97, 1201-1209. [CrossRef] [PubMed]

272. Inoue, H.; Kobayashi-Hattori, K.; Horiuchi, Y.; Oishi, Y.; Arai, S.; Takita, T. Regulation of the body fat percentage in developmental-stage rats by methylxanthine derivatives in a high-fat diet. Biosci. Biotechnol. Biochem. 2006, 70, 1134-1139. [CrossRef] [PubMed]

273. Heppel, L.A.; Porterfield, V.T.; Peake, E.G. The lipotropic activity of caffeine, theobromine and theophylline. Arch. Biochem. Biophys. 1947, 15, 439-443.

274. Bray, G.A.; Mothon, S.; Cohen, A.S. Mobilization of fatty acids in genetically obese rats. J. Lipid Res. 1970, 11, 517-521. [PubMed]

275. Kuo, J.F.; de Renzo, E.C. A comparison of the effects of lipolytic and antilipolytic agents on adenosine $3^{\prime}, 5^{\prime}$-monophosphate levels in adipose cells as determined by prior labeling with adenine- $8-{ }^{14} \mathrm{C}$. J. Biol. Chem. 1969, 244, 2252-2260. [PubMed]

276. Acheson, K.J.; Gremaud, G.; Meirim, I.; Montigon, F.; Krebs, Y.; Fay, L.B.; Gay, L.-J.; Schneiter, P.; Schindler, C.; Tappy, L. Metabolic effects of caffeine in humans: Lipid oxidation or futile cycling? Am. J. Clin. Nutr. 2004, 79, 40-46. [PubMed] 
277. Kim, T.-W.; Shin, Y.-O.; Lee, J.-B.; Min, Y.-K.; Yang, H.-M. Effect of caffeine on the metabolic responses of lipolysis and activated sweat gland density in human during physical activity. Food Sci. Biotechnol. 2010, 19, 1077-1081. [CrossRef]

278. Lopez-Garcia, E.; van Dam, R.M.; Rajpathak, S.; Willett, W.C.; Manson, J.E.; Hu, F.B. Changes in caffeine intake and long-term weight change in men and women. Am. J. Clin. Nutr. 2006, 83, 674-680. [PubMed]

279. Westerterp-Plantenga, M.S.; Lejeune, M.P.G.M.; Kovacs, E.M.R. Body weight loss and weight maintenance in relation to habitual caffeine intake and green tea supplementation. Obes. Res. 2005, 13, 1195-1204. [CrossRef] [PubMed]

280. Davis, J.O.; Shock, N.W. The effect of theophylline ethylene diamine on renal function in control subjects and in patients with congestive heart failure. J. Clin. Investig. 1949, 28 Pt. 2, 1459-1468. [CrossRef] [PubMed]

281. Osswald, H.; Schnermann, J. Methylxanthines and the kidney. Handb. Exp. Pharmacol. 2011, 200, $391-412$. [PubMed]

282. Wilcox, C.S.; Welch, W.J.; Schreiner, G.F.; Belardinelli, L. Natriuretic and diuretic actions of a highly selective adenosine $\mathrm{A}_{1}$ receptor antagonist. J. Am. Soc. Nephrol. 1999, 10, 714-720. [PubMed]

283. Rieg, T.; Steigele, H.; Schnermann, J.; Richter, K.; Osswald, H.; Vallon, V. Requirement of intact adenosine $A_{1}$ receptors for the diuretic and natriuretic action of the methylxanthines theophylline and caffeine. J. Pharmacol. Exp. Ther. 2005, 313, 403-409. [CrossRef] [PubMed]

284. Fredholm, B.B.; Hedqvist, P.; Vernet, L. Effect of theophylline and other drugs on rabbit renal cyclic nucleotide phosphodiesterase, 5'-nucleotidase and adenosine deaminase. Biochem. Pharmacol. 1978, 27, 2845-2850. [CrossRef]

285. Coulson, R.; Scheinman, S.J. Xanthine effects on renal proximal tubular function and cyclic AMP metabolism. J. Pharmacol. Exp. Ther. 1989, 248, 589-595. [PubMed]

286. Bhupathiraju, S.N.; Pan, A.; Malik, V.S.; Manson, J.E.; Willett, W.C.; van Dam, R.M.; Hu, F.B. Caffeinated and caffeine-free beverages and risk of type 2 diabetes. Am. J. Clin. Nutr. 2013, 97, 155-166. [CrossRef] [PubMed]

287. Biessels, G.J. Caffeine, diabetes, cognition, and dementia. J. Alzheimers Dis. 2010, 20 (Suppl. S1), S143-S150. [PubMed]

288. Bidel, S.; Hu, G.; Qiao, Q.; Jousilahti, P.; Antikainen, R.; Tuomilehto, J. Coffee consumption and risk of total and cardiovascular mortality among patients with type 2 diabetes. Diabetologia 2006, 49, 2618-2626. [CrossRef] [PubMed]

289. Muley, A.; Muley, P.; Shah, M. Coffee to reduce risk of type 2 diabetes? A systematic review. Curr. Diabetes Rev. 2012, 8, 162-168. [CrossRef] [PubMed]

290. Van Dam, R.M.; Feskens, E.J.M. Coffee consumption and risk of type 2 diabetes mellitus. Lancet 2002, 360, 1477-1478. [CrossRef]

291. Van Dam, R.M.; Hu, F.B. Coffee consumption and risk of type 2 diabetes: A systematic review. JAMA 2005, 294, 97-104. [CrossRef] [PubMed]

292. Paynter, N.P.; Yeh, H.-C.; Voutilainen, S.; Schmidt, M.I.; Heiss, G.; Folsom, A.R.; Brancati, F.L.; Kao, W.H.L. Coffee and sweetened beverage consumption and the risk of type 2 diabetes mellitus: The atherosclerosis risk in communities study. Am. J. Epidemiol. 2006, 164, 1075-1084. [CrossRef] [PubMed]

293. Sartorelli, D.S.; Fagherazzi, G.; Balkau, B.; Touillaud, M.S.; Boutron-Ruault, M.-C.; de Lauzon-Guillain, B.; Clavel-Chapelon, F. Differential effects of coffee on the risk of type 2 diabetes according to meal consumption in a French cohort of women: The E3N/EPIC cohort study. Am. J. Clin. Nutr. 2010, 91, 1002-1012. [CrossRef] [PubMed]

294. Ding, M.; Bhupathiraju, S.N.; Chen, M.; van Dam, R.M.; Hu, F.B. Caffeinated and decaffeinated coffee consumption and risk of type 2 diabetes: A systematic review and a dose-response meta-analysis. Diabetes Care 2014, 37, 569-586. [CrossRef] [PubMed]

295. Dieren, S.; Uiterwaal, C.S.P.M.; Schouw, Y.T.; van der A, D.L.; Boer, J.M.A.; Spijkerman, A.; Grobbee, D.E.; Beulens, J.W.J. Coffee and tea consumption and risk of type 2 diabetes. Diabetologia 2009, 52, 2561-2569. [CrossRef] [PubMed]

296. Yang, W.-S.; Wang, W.-Y.; Fan, W.-Y.; Deng, Q.; Wang, X. Tea consumption and risk of type 2 diabetes: A dose-response meta-analysis of cohort studies. Br. J. Nutr. 2014, 111, 1329-1339. [CrossRef] [PubMed]

297. Pereira, M.A.; Parker, E.D.; Folsom, A.R. Coffee consumption and risk of type 2 diabetes mellitus: An 11-year prospective study of 28,812 postmenopausal women. Arch. Intern. Med. 2006, 166, 1311-1316. [CrossRef] [PubMed] 
298. Van Dam, R.M.; Willett, W.C.; Manson, J.E.; Hu, F.B. Coffee, caffeine, and risk of type 2 diabetes: A prospective cohort study in younger and middle-aged U.S. women. Diabetes Care 2006, 29, 398-403. [CrossRef] [PubMed]

299. Sarriá, B.; Martínez-López, S.; Sierra-Cinos, J.L.; Garcia-Diz, L.; Goya, L.; Mateos, R.; Bravo, L. Effects of bioactive constituents in functional cocoa products on cardiovascular health in humans. Food Chem. 2015, 174, 214-218. [CrossRef] [PubMed]

300. Seino, S.; Takahashi, H.; Fujimoto, W.; Shibasaki, T. Roles of cAMP signalling in insulin granule exocytosis. Diabetes Obes. Metab. 2009, 11, 180-188. [CrossRef] [PubMed]

301. Vilela, V.R.; de Oliveira, A.L.; Comar, J.F.; Peralta, R.M.; Bracht, A. Tadalafil inhibits the cAMP stimulated glucose output in the rat liver. Chem. Biol. Interact. 2014, 220,1-11. [CrossRef] [PubMed]

302. Huang, M.-T.; Xie, J.-G.; Wang, Z.Y.; Ho, C.-T.; Lou, Y.-R.; Wang, C.-X.; Hard, G.C.; Conney, A.H. Effects of tea, decaffeinated tea, and caffeine on UVB light-induced complete carcinogenesis in SKH-1 mice: Demonstration of caffeine as a biologically important constitutent of tea. Cancer Res. 1997, 57, 2623-2629. [PubMed]

303. Lu, Y.-P.; Lou, Y.-R.; Xie, J.-G.; Peng, Q.-Y.; Liao, J.; Yang, C.S.; Huang, M.-T.; Conney, A.H. Topical applications of caffeine or (-)-epigallocatechin gallate (EGCG) inhibit carcinogenesis and selectively increase apoptosis in UVB-induced skin tumors in mice. Proc. Natl. Acad. Sci. USA 2002, 99, 12455-12460. [CrossRef] [PubMed]

304. Lu, Y.-P.; Lou, Y.-R.; Xie, J.-G.; Peng, Q.-Y.; Zhou, S.; Lin, Y.; Shih, W.J.; Conney, A.H. Caffeine and caffeine sodium benzoate have a sunscreen effect, enhance UVB-induced apoptosis, and inhibit UVB-induced skin carcinogenesis in SKH-1 mice. Carcinogenesis 2006, 28, 199-206. [CrossRef] [PubMed]

305. Ryzhov, S.; McCaleb, J.L.; Goldstein, A.E.; Biaggioni, I.; Feoktistov, I. Role of Adenosine Receptors in the Regulation of Angiogenic Factors and Neovascularization in Hypoxia. J. Pharmacol. Exp. Ther. 2007, 320, 565-572. [CrossRef] [PubMed]

306. Chung, F.-L.; Wang, M.; Rivenson, A.; Iatropoulos, M.J.; Reinhardt, J.C.; Pittman, B.; Ho, C.-T.; Amin, S.G. Inhibition of lung carcinogenesis by black tea in fischer rats treated with a tobacco-specific carcinogen: Caffeine as an important constituent. Cancer Res. 1998, 58, 4096-4101. [PubMed]

307. Lu, G.; Liao, J.; Yang, G.; Reuhl, K.R.; Hao, X.; Yang, C.S. Inhibition of adenoma progression to adenocarcinoma in a 4-(methylnitrosamino)-1-(3-pyridyl)-1-butanone-Induced lung tumorigenesis model in A/J mice by tea polyphenols and caffeine. Cancer Res. 2006, 66, 11494-11501. [CrossRef] [PubMed]

308. Yang, H.; Rouse, J.; Lukes, L.; Lancaster, M.; Veenstra, T.; Zhou, M.; Shi, Y.; Park, Y.-G.; Hunter, K. Caffeine suppresses metastasis in a transgenic mouse model: A prototype molecule for prophylaxis of metastasis. Clin. Exp. Metastasis 2005, 21, 719-735. [CrossRef]

309. Gude, R.P.; Menon, L.G.; Rao, S.G. Effect of Caffeine, a xanthine derivative, in the inhibition of experimental lung metastasis induced by B16F10 melanoma cells. J. Exp. Clin. Cancer Res. 2001, 20, 287-292. [PubMed]

310. Merighi, S.; Benini, A.; Mirandola, P.; Gessi, S.; Varani, K.; Simioni, C.; Leung, E.; Maclennan, S.; Baraldi, P.G.; Borea, P.A. Caffeine inhibits adenosine-induced accumulation of hypoxia-inducible factor- $1 \alpha$, vascular endothelial growth factor, and interleukin-8 expression in hypoxic human colon cancer cells. Mol. Pharmacol. 2007, 72, 395-406. [CrossRef] [PubMed]

311. Shukla, V.; Gude, R.P. Potentiation of lipid peroxidation in B16F10 and B16F1 melanoma cells by caffeine, a methylxanthine derivative: Relationship to intracellular glutathione. Chemotherapy 2003, 49, 71-75. [CrossRef] [PubMed]

312. Hashimoto, T.; He, Z.; Ma, W.-Y.; Schmid, P.C.; Bode, A.M.; Yang, C.S.; Dong, Z. Caffeine inhibits cell proliferation by G0/G1 phase arrest in JB6 cells. Cancer Res. 2004, 64, 3344-3349. [CrossRef] [PubMed]

313. Makower, D.; Malik, U.; Novik, Y.; Wiernik, P.H. Therapeutic efficacy of theophylline in chronic lymphocytic leukemia. Med. Oncol. 1999, 16, 69-71. [CrossRef] [PubMed]

314. Basu, S.; Mitra Basu, R. Theophylline as a therapy for chronic lymphocytic leukemia: A case report and review of literature. Haematologia 2000, 30, 225-227. [CrossRef] [PubMed]

315. Hirsh, L.; Dantes, A.; Suh, B.-S.; Yoshida, Y.; Hosokawa, K.; Tajima, K.; Kotsuji, F.; Merimsky, O.; Amsterdam, A. Phosphodiesterase inhibitors as anti-cancer drugs. Biochem. Pharmacol. 2004, 68, 981-988. [CrossRef] [PubMed]

316. Barcz, E.; Sommer, E.; Sokolnicka, I.; Gawrychowski, K.; Roszkowska-Purska, K.; Janik, P.; Skopinska-Rózewska, E. The influence of theobromine on angiogenic activity and proangiogenic cytokines production of human ovarian cancer cells. Oncol. Rep. 1998, 5, 517-537. [CrossRef] [PubMed] 
317. Barcz, E.; Sommer, E.; Janik, P.; Marianowski, L.; Skopinska-Rózewska, E. Adenosine receptor antagonism causes inhibition of angiogenic activity of human ovarian cancer cells. Oncol. Rep. 2000, 7, 1285-1291. [CrossRef] [PubMed]

318. Gil, M.; Skopińska-Rózewska, E.; Radomska, D.; Demkow, U.; Skurzak, H.; Rochowska, M.; Beuth, J.; Roszkowski, K. Effect of purinergic receptor antagonists suramin and theobromine on tumor-induced angiogenesis in BALB/c mice. Folia Biol. 1993, 39, 63-68.

319. Takahashi, M.; Yanoma, S.; Yamamoto, Y.; Rino, Y.; Amano, T.; Imada, T. Combined effect of CDDP and caffeine against human gastric cell line in vivo. Anticancer Res. 1998, 18, 4399-4401. [PubMed]

320. Fingert, H.J.; Pu, A.T.; Chen, Z.Y.; Perdee, A.B. In vivo and in vitro enhanced antitumour effect by pentoxifylline in human cancer cells treated with Thiothepa. Cancer Res. 1988, 48, 4375-4381. [PubMed]

321. Fingert, H.J.; Chang, J.D.; Pardee, A.B. Cytotoxic, cell cycle, and chromosomal effects of methylxanthines in human tumor cells treated with alkylating agents. Cancer Res. 1986, 46, 2463-2467. [PubMed]

322. Kawahara, M.; Takashi, Y.; Takazawa, K.; Tsuchiya, H.; Tomita, K.; Yokogawa, K.; Miyamoto, K.-I. Caffeine Dose-dependently Potentiates the Antitumor Effect of Cisplatin on Osteosarcomas. Anticancer Res. 2008, 28, 1681-1685. [PubMed]

323. Miwa, S.; Kitamura, S.; Shirai, T.; Hayashi, K.; Nishida, H.; Takeuchi, A.; Nojima, T.; Tsuchiya, H. Desmoplastic small round cell tumour successfully treated with caffeine-assisted chemotherapy: A case report and review of the literature. Anticancer Res. 2010, 30, 3769-3774. [PubMed]

324. Hayashi, M.; Tsuchiya, H.; Yamamoto, N.; Karita, M.; Shirai, T.; Nishida, H.; Takeuchi, A.; Tomita, K. Caffeine-potentiated chemotherapy for metastatic carcinoma and lymphoma of bone and soft tissue. Anticancer Res. 2005, 25, 2399-2405. [PubMed]

325. Kakuyama, A.; Sadzuka, Y. Effect of methylxanthine derivatives on doxorubicin transport and antitumor activity. Curr. Drug Metab. 2001, 2, 379-395. [CrossRef] [PubMed]

326. Tsuchiya, H.; Yasutake, H.; Yokogawa, A.; Baba, H.; Ueda, Y.; Tomita, K. Effect of chemotherapy combined with caffeine for osteosarcoma. J. Cancer Res. Clin. Oncol. 1992, 118, 567-569. [CrossRef] [PubMed]

327. Busse, P.M.; Bose, S.K.; Jones, R.W.; Tolmach, L.J. The action of caffeine on X-Irradiated HeLa cells: III. Enhancement of X-ray-induced killing during G2 arrest. Radiat. Res. 1978, 76, 292-307. [CrossRef] [PubMed]

328. Malki, A.M.; Gentry, J.; Evans, S.C. Differential effect of selected methylxanthine derivatives on radiosensitization of lung carcinoma cells. Exp. Oncol. 2006, 28, 16-24. [PubMed]

329. Youn, H.; Hee Kook, Y.; Oh, E.-T.; Jeong, S.-Y.; Kim, C.; Kyung Choi, E.; Uk Lim, B.; Park, H.J. 1-Methylxanthine enhances the radiosensitivity of tumor cells. Int. J. Radiat. Biol. 2009, 85, 167-174. [CrossRef] [PubMed]

330. Bode, A.M.; Dong, Z. The enigmatic effects of caffeine in cell cycle and cancer. Cancer Lett. 2007, $247,26-39$. [CrossRef] [PubMed]

331. Sabisz, M.; Skladanowski, A. Modulation of cellular response to anticancer treatment by caffeine: Inhibition of cell cycle checkpoints, DNA repair and more. Curr. Pharm. Biotechnol. 2008, 9, 325-336. [CrossRef] [PubMed]

332. Zhou, B.-B.S.; Chaturvedi, P.; Spring, K.; Scott, S.P.; Johanson, R.A.; Mishra, R.; Mattern, M.R.; Winkler, J.D.; Khanna, K.K. Caffeine abolishes the mammalian G2/M DNA damage checkpoint by inhibiting ataxia-telangiectasia-mutated kinase activity. J. Biol. Chem. 2000, 275, 10342-10348. [CrossRef] [PubMed]

333. Kawabe, T. G2 checkpoint abrogators as anticancer drugs. Mol. Cancer Ther. 2004, 3, 513-519. [PubMed]

334. Jha, M.N.; Bamburg, J.R.; Bernstein, B.W.; Bedford, J.S. Caffeine eliminates $\gamma$-ray-induced G2-phase delay in human tumor cells but not in normal cells. Radiat. Res. 2002, 157, 26-31. [CrossRef]

335. Dias, T.R.; Alves, M.G.; Bernardino, R.L.; Martins, A.D.; Moreira, A.C.; Silva, J.; Barros, A.; Sousa, M.; Silva, B.M.; Oliveira, P.F. Dose-dependent effects of caffeine in human Sertoli cells metabolism and oxidative profile: Relevance for male fertility. Toxicology 2015, 328, 12-20. [CrossRef] [PubMed]

336. Kopf, G.S.; Lewis, C.A.; Vacquier, V.D. Characterization of basal and methylxanthine-stimulated Ca ${ }^{2+}$ transport in abalone spermatozoa. J. Biol. Chem. 1984, 259, 5514-20. [PubMed]

337. Tash, J.S.; Means, A.R. Regulation of protein phosphorylation and motility of sperm by cyclic adenosine monophosphate and calcium. Biol. Reprod. 1982, 26, 745-763. [CrossRef] [PubMed]

338. Brokaw, C.J. Regulation of sperm flagellar motility by calcium and cAMP-dependent phosphorylation. J. Cell. Biochem. 1987, 35, 175-184. [CrossRef] [PubMed] 
339. Dias, T.R.; Alves, M.G.; Tomás, G.D.; Socorro, S.; Silva, B.M.; Oliveira, P.F. White tea as a promising antioxidant medium additive for sperm storage at room temperature: A comparative study with green tea. J. Agric. Food Chem. 2014, 62, 608-617. [CrossRef] [PubMed]

340. Yamaguchi, S.; Funahashi, H.; Murakami, T. Improved fertility in gilts and sows after artificial insemination of frozen-thawed boar semen by supplementation of semen extender with caffeine and $\mathrm{CaCl}_{2}$. J. Reprod. Dev. 2009, 55, 645-649. [CrossRef] [PubMed]

341. Klemmer, I.; Yagi, S.; Gressner, O.A. Oral application of 1,7-dimethylxanthine (paraxanthine) attenuates the formation of experimental cholestatic liver fibrosis. Hepatol. Res. 2011, 41, 1094-1109. [CrossRef] [PubMed]

342. Modi, A.A.; Feld, J.J.; Park, Y.; Kleiner, D.E.; Everhart, J.E.; Liang, T.J.; Hoofnagle, J.H. Increased caffeine consumption is associated with reduced hepatic fibrosis. Hepatology 2010, 51, 201-209. [CrossRef] [PubMed]

343. Grases, F.; Rodriguez, A.; Costa-Bauza, A. Theobromine inhibits uric acid crystallization. A potential application in the treatment of uric acid nephrolithiasis. PLoS ONE 2014, 9, e111184. [CrossRef] [PubMed]

344. Cui, D.; Trier, K.; Zeng, J.; Wu, K.; Yu, M.; Hu, J.; Chen, X.; Ge, J. Effects of 7-methylxanthine on the sclera in form deprivation myopia in guinea pigs. Acta Ophthalmol. 2011, 89, 328-334. [CrossRef] [PubMed]

345. Trier, K.; Munk Ribel-Madsen, S.; Cui, D.; Brøgger Christensen, S. Systemic 7-methylxanthine in retarding axial eye growth and myopia progression: A 36-month pilot study. J. Ocul. Biol. Dis. Inform. 2008, 1, 85-93. [CrossRef] [PubMed]

346. Pollard, I.; Williamson, S.; Magre, S. Influence of caffeine administered during pregnancy on the early differentiation of fetal rat ovaries and testes. J. Dev. Physiol. 1990, 13, 59-65. [PubMed]

347. Chorostowska-Wynimko, J.; Skopińska-Rózewska, E.; Sommer, E.; Rogala, E.; Skopiński, P.; Wojtasik, E. Multiple effects of theobromine on fetus development and postnatal status of the immune system. Int. J. Tissue React. 2004, 26, 53-60. [PubMed]

348. Skopiński, P.; Woronkowicz, M.; Skopińska-Różewska, E.; Siwicki, A. The effects of prenatal exposure to methylxanthines. Pol. J. Vet. Sci. 2011, 14, 695-701. [CrossRef] [PubMed]

349. Browne, M.L.; Bell, E.M.; Druschel, C.M.; Gensburg, L.J.; Mitchell, A.A.; Lin, A.E.; Romitti, P.A.; Correa, A. Maternal caffeine consumption and risk of cardiovascular malformations. Birth Defects Res. Part A Clin. Mol. Teratol. 2007, 79, 533-543. [CrossRef] [PubMed]

350. Jahanfar, S.; Jaafar, S.H. Effects of restricted caffeine intake by mother on fetal, neonatal and pregnancy outcome. Cochrane Database Syst. Rev. 2013, 2, CD006965. [CrossRef] [PubMed]

351. Barr, H.M.; Streissguth, A.P. Caffeine use during pregnancy and child outcome: A 7-year prospective study. Neurotoxicol. Teratol. 1991, 13, 441-448. [CrossRef]

352. Bech, B.H.; Obel, C.; Henriksen, T.B.; Olsen, J. Effect of reducing caffeine intake on birth weight and length of gestation: Randomised controlled trial. BMJ Br. Med. J. 2007, 334, 409-409. [CrossRef] [PubMed]

353. Browne, M.L.; Hoyt, A.T.; Feldkamp, M.L.; Rasmussen, S.A.; Marshall, E.G.; Druschel, C.M.; Romitti, P.A. Maternal caffeine intake and risk of selected birth defects in the national birth defects prevention study. Birth Defects Res. Part A Clin. Mol. Teratol. 2011, 91, 93-101. [CrossRef] [PubMed]

354. Group, C.S. Maternal caffeine intake during pregnancy and risk of fetal growth restriction: A large prospective observational study. BMJ Br. Med. J. 2008, 337, a2332. [CrossRef]

355. Weng, X.; Odouli, R.; Li, D.-K. Maternal caffeine consumption during pregnancy and the risk of miscarriage: A prospective cohort study. Am. J. Obstet. Gynecol. 2008, 198, 279.e1-279.e8. [CrossRef] [PubMed]

356. Schmidt, R.J.; Romitti, P.A.; Burns, T.L.; Browne, M.L.; Druschel, C.M.; Olney, R.S. Maternal caffeine consumption and risk of neural tube defects. Birth Defects Res. Part A Clin. Mol. Teratol. 2009, 85, 879-889. [CrossRef] [PubMed]

357. Hoyt, A.T.; Browne, M.; Richardson, S.; Romitti, P.; Druschel, C. Maternal caffeine consumption and small for gestational age births: Results from a population-based case-control study. Matern. Child Health J. 2013, 18, 1540-1551. [CrossRef] [PubMed]

358. Chen, L.; Bell, E.M.; Browne, M.L.; Druschel, C.M.; Romitti, P.A.; Schmidt, R.J.; Burns, T.L.; Moslehi, R.; Olney, R.S.; National Birth Defects Prevention Study. Maternal caffeine consumption and risk of congenital limb deficiencies. Birth Defects Res. Part A Clin. Mol. Teratol. 2012, 94, 1033-1043. [CrossRef] [PubMed]

359. Kuczkowski, K.M. Caffeine in pregnancy. Arch. Gynecol. Obstet. 2009, 280, 695-698. [CrossRef] [PubMed]

360. Friedman, L.; Weinberger, M.A.; Farber, T.M.; Moreland, F.M.; Peters, E.L.; Gilmore, C.E.; Khan, M.A. Testicular atrophy and impaired spermatogenesis in rats fed high levels of the methylxanthines caffeine, theobromine, or theophylline. J. Environ. Pathol. Toxicol. 1979, 2, 687-706. [PubMed] 
361. Gans, J.H. Comparative toxicities of dietary caffeine and theobromine in the rat. Food Chem. Toxicol. 1984, 22, 365-369. [CrossRef]

362. Cappelletti, S.; Daria, P.; Sani, G.; Aromatario, M. Caffeine: Cognitive and physical performance enhancer or psychoactive drug? Curr. Neuropharmacol. 2015, 13, 71-88. [CrossRef] [PubMed]

363. Hart, A.B.; de Wit, H.; Palmer, A.A. Genetic factors modulating the response to stimulant drugs in humans. Curr. Top. Behav. Neurosci. 2012, 12, 537-577. [PubMed]

364. Rogers, P.J.; Hohoff, C.; Heatherley, S.V.; Mullings, E.L.; Maxfield, P.J.; Evershed, R.P.; Deckert, J.; Nutt, D.J. Association of the anxiogenic and alerting effects of caffeine with ADORA2A and ADORA1 polymorphisms and habitual level of caffeine consumption. Neuropsychopharmacology 2010, 35, 1973-1983. [CrossRef] [PubMed]

365. Alsene, K.; Deckert, J.; Sand, P.; de Wit, H. Association between $A_{2 A}$ receptor gene polymorphisms and caffeine-induced anxiety. Neuropsychopharmacology 2003, 28, 1694-1702. [CrossRef] [PubMed]

366. Planning Committee for a Workshop on Potential Health Hazards Associated with Consumption of Caffeine in Food and Dietary Supplements; Food and Nutrition Board; Board on Health Sciences Policy; Institute of Medicine. In Caffeine in Food and Dietary Supplements: Examining Safety: Workshop Summary; National Academies Press (US): Washington DC, USA, 2014.

367. Glade, M.J. Caffeine-Not just a stimulant. Nutrition 2010, 26, 932-938. [CrossRef] [PubMed]

368. Clauson, K.A.; Shields, K.M.; McQueen, C.E.; Persad, N. Safety issues associated with commercially available energy drinks. J. Am. Pharm. Assoc. 2003, 48, 55-63. [CrossRef] [PubMed]

369. Banerjee, P.; Ali, Z.; Levine, B.; Fowler, D.R. Fatal caffeine intoxication: A series of eight cases from 1999 to 2009. J. Forensic Sci. 2014, 59, 865-868. [CrossRef] [PubMed]

370. Stavric, B. Methylxanthines: Toxicity to humans. 2. Caffeine. Food Chem. Toxicol. 1988, 26, 645-662. [CrossRef]

371. Tajima, Y. Coffee-induced hypokalaemia. Clin. Med. Insights Case Rep. 2010, 3, 9-13. [CrossRef] [PubMed]

372. Nehlig, A. Dependence upon coffee and caffeine: An update. In Coffee, Tea, Chocolate, and the Brain; Nehlig, A., Ed.; CRC Press: Boca Raton, FL, USA, 2004; pp. 133-146.

373. Nehlig, A.; Armspach, J.-P.; Namer, I.J. SPECT assessment of brain activation induced by caffeine: No effect on areas involved in dependence. Dialogues Clin. Neurosci. 2010, 12, 255-263. [PubMed]

374. Baggott, M.J.; Childs, E.; Hart, A.B.; de Bruin, E.; Palmer, A.A.; Wilkinson, J.E.; de Wit, H. Psychopharmacology of theobromine in healthy volunteers. Psychopharmacology 2013, 228, 109-118. [CrossRef] [PubMed]

375. Eteng, M.U.; Eyong, E.U.; Akpanyung, E.O.; Agiang, M.A.; Aremu, C.Y. Recent advances in caffeine and theobromine toxicities: A review. Plant Foods Hum. Nutr. 1997, 51, 231-243. [CrossRef] [PubMed]

376. Czok, G. Concerning the question of the biological effectiveness of methylxanthines in cocoa products. Z. Ernährungswissenschaft 1974, 4, 165-170. [CrossRef]

377. Knight, R.J.; Bowmer, C.J.; Yates, M.S. The diuretic action of 8-cyclopentyl-1,3-dipropylxanthine, a selective A1 adenosine receptor antagonist. Br. J. Pharmacol. 1993, 109, 271-277. [CrossRef] [PubMed]

(C) 2016 by the authors; licensee MDPI, Basel, Switzerland. This article is an open access article distributed under the terms and conditions of the Creative Commons Attribution (CC-BY) license (http://creativecommons.org/licenses/by/4.0/). 